\title{
Immunomodulatory Effects Mediated by Serotonin
}

\author{
Rodrigo Arreola, ${ }^{1}$ Enrique Becerril-Villanueva, ${ }^{2}$ Carlos Cruz-Fuentes, ${ }^{1}$ \\ Marco Antonio Velasco-Velázquez, ${ }^{3}$ María Eugenia Garcés-Alvarez, \\ Gabriela Hurtado-Alvarado, ${ }^{4}$ Saray Quintero-Fabian, ${ }^{5}$ and Lenin Pavón ${ }^{2}$

\begin{abstract}
${ }^{1}$ Psychiatric Genetics Department, Clinical Research Branch, National Institute of Psychiatry, "Ramón de la Fuente", Calzada México-Xochimilco 101, Colonia San Lorenzo Huipulco, Tlalpan, 14370 Mexico City, DF, Mexico

${ }^{2}$ Department of Psychoimmunology, National Institute of Psychiatry, "Ramón de la Fuente", Calzada México-Xochimilco 101, Colonia San Lorenzo Huipulco, Tlalpan, 14370 Mexico City, DF, Mexico

${ }^{3}$ School of Medicine, National Autonomous University of Mexico, Avenida Universidad 3000, Coyoacan, 04510 Mexico City, DF, Mexico

${ }^{4}$ Area of Neurosciences, Department of Biology of Reproduction, CBS, Universidad Autonoma Metropolitana, Unidad Iztapalapa, Avenida San Rafael Atlixco No. 186, Colonia Vicentina, Iztapalapa, 09340 Mexico City, DF, Mexico

${ }^{5}$ Genetics Unit Nutrition of Biomedical Research Institute of Universidad Nacional Autónoma de México at Instituto Nacional de Pediatría, Avenida del Iman No. 1, cuarto piso, Colonia Insurgentes-Cuicuilco, Coyoacan, 04530 Mexico City, DF, Mexico
\end{abstract}

Correspondence should be addressed to Lenin Pavón; lkuriaki@imp.edu.mx

Received 20 October 2014; Accepted 24 February 2015

Academic Editor: Douglas C. Hooper

Copyright (C) 2015 Rodrigo Arreola et al. This is an open access article distributed under the Creative Commons Attribution License, which permits unrestricted use, distribution, and reproduction in any medium, provided the original work is properly cited.

Serotonin (5-HT) induces concentration-dependent metabolic effects in diverse cell types, including neurons, entherochromaffin cells, adipocytes, pancreatic beta-cells, fibroblasts, smooth muscle cells, epithelial cells, and leukocytes. Three classes of genes regulating 5-HT function are constitutively expressed or induced in these cells: (a) membrane proteins that regulate the response to 5-HT, such as SERT, 5HTR-GPCR, and the 5 $\mathrm{HT}_{3}$-ion channels; (b) downstream signaling transduction proteins; and (c) enzymes controlling 5-HT metabolism, such as IDO and MAO, which can generate biologically active catabolites, including melatonin, kynurenines, and kynurenamines. This review covers the clinical and experimental mechanisms involved in 5-HTinduced immunomodulation. These mechanisms are cell-specific and depend on the expression of serotonergic components in immune cells. Consequently, 5-HT can modulate several immunological events, such as chemotaxis, leukocyte activation, proliferation, cytokine secretion, anergy, and apoptosis. The effects of 5-HT on immune cells may be relevant in the clinical outcome of pathologies with an inflammatory component. Major depression, fibromyalgia, Alzheimer disease, psoriasis, arthritis, allergies, and asthma are all associated with changes in the serotonergic system associated with leukocytes. Thus, pharmacological regulation of the serotonergic system may modulate immune function and provide therapeutic alternatives for these diseases.

\section{Introduction}

Serotonin (5-HT), also known as 5-hydroxytryptamine or 3(2-aminoetil)-1H-indol-5-ol, is a monoamine containing two nitrogen molecules: the first nitrogen is basic and embedded within the indol-5-ol; the second, within 2-aminoethyl, is located at the terminus of the aliphatic chain. 5-HT is generated from tryptophan and serves as a substrate for the synthesis of a diverse set of molecules, such as melatonin, formyl-5-hydroxykynurenamine, and 5-hydroxyindoleacetic acid [1]. In addition, 5-HT is a signaling molecule that affects the immune [2], gastrointestinal [3], and nervous [4] systems in paracrine, endocrine, and juxtacrine fashion. Finally, 5HT regulates development during cellular differentiation and ontogeny (morphogenesis) in several cell linages [5-7].

The majority of 5-HT synthesis, up to $90 \%$, takes place in gastrointestinal enterochromaffin (EC) cells, followed by synthesis in myenteric neurons $(5 \%)$ and the brain $[8,9]$. In the 1980s, 5-HT was identified as an immunomodulator for its ability to stimulate or inhibit inflammation [10]. This immune regulation - which has yet to be fully elucidated-is orchestrated by the serotonergic system. Therefore, to understand disease pathologies related to the immune system, it is 
important to consider the function of serotonergic components. Specifically, insight can be gained by understanding how serotonergic components are related to mechanisms of immune modulation that depend on 5-HT receptors (5HTR) expression in leukocytes and other cells involved in an inflammatory response.

\section{A Brief History of 5-HT Discovery}

The discovery of 5-HT was a product of collaborative endeavors initiated in the last quarter of the 19th century [11] that lasted into the second half of the 20th century. Initial studies identified an extract with vasoconstriction properties from a platelet fraction of uncoagulated blood [12]. In research conducted in Rome during the 1930s, Vittorio Erspamer isolated a molecule from gastrointestinal EC cells with the capacity to generate smooth muscle contractions in a rat uterus. Chemical analysis identified the molecule as an indoleamine and it was named enteramine [13]. During the 1940s in the Cleveland Clinic research department, Maurice Rapport, Arda Green, and Irving Page purified and characterized a vasoconstrictor compound generated shortly after coagulation and related to hypertension. In a tour de force, the molecule was purified from 900 liters of serum obtained from 2 tons of bull's blood [14, 15]. The name serotonin emerged after the substance was crystallized in 1948 because it was obtained from serum ("ser") and could induce vascular tone ("tonin") in blood vessels [16]. Subsequently, the crystalline vasoconstrictor substance was shown to be a single complex composed of creatinine and indol-derivates, which permitted a structural model of 5-HT based on UV-spectrophotometry [17]. Chemical synthesis of 5-HT by Hamlin and Fischer in 1951 [18] provided significant progress allowing for the confirmation of its pharmacological effects [19] and a comparison with the previously isolated enteramine [20]. Interest in understanding the physiological role of 5-HT prompted efforts to isolate the compound from different mammals and tissues, such as the central nervous system [21].

Since the 1970s there has been an established association between the serotonergic system and affective disorders as well as mood changes [22]. Recently, serotonin has been associated with a myriad of processes [23], including aggression [24], sleep [25], appetite [26], pain [27], bone density [28], tissue regeneration [29], platelet aggregation [30], and gastrointestinal function [31]. The influence of 5-HT on the immune system has also been recognized, although the specific mechanisms underlying these effects are not completely understood and may require confirmation in human cells. Despite these pitfalls, it is well acknowledged that the serotonergic system and associated molecules expressed in immune cells can influence mood disorders, such as major depression [32] and schizophrenia [33, 34].

\section{Components of the Serotonergic System Are Expressed in Leukocytes}

The expression of serotonergic components is differentially regulated between tissues and cell types. While the expression and function of serotonergic proteins has primarily been studied within the central nervous system [81], it should be pointed out that no functional differences between cell types have been identified. The serotonergic components expressed in the immune system encompass a complex ensemble of proteins that coordinate the synthesis and degradation [1], transport and storage [58], and response to 5-HT stimulation [40]. In leukocytes, the expression of serotonergic components (Table 1) is modulated by the concentration of extracellular and intracellular 5-HT. Furthermore, the signals generated by 5-HT interactions with leukocytes are distinct depending on function, developmental stage, and activation status of the cell. This functional heterogeneity suggests that the serotonergic system can precisely regulate a wide range of immunomodulatory effects [81].

3.1. Catabolism and Anabolism of 5-HT. The essential amino acid Tryptophan is utilized by many cell types and can be converted into a wide range of chemically related products, among the best known are 5-HT and melatonin, but also include kynurenines and kynurenamines (Figure 1). In macrophages and T lymphocytes the indoleamine 2,3-dioxygenase (IDO1 \& IDO2. EC: 1.13.11.52) $[60,82]$ enzymes help degrade tryptophan to generate kynurenines and produce kynurenamines from 5-HT or melatonin [83]. In general, all of these compounds can modulate immune responses [1, 8486]. However, the mechanisms by which these molecules exert an immunomodulating function are not completely elucidated. Some observations suggest that kynurenines and kynurenamines function in negative feedback loops to modulate 5-HT-mediated inflammation, other proinflammatory molecules, and melatonin levels.

3.1.1. Anabolism. The synthesis of serotonin begins with the essential amino acid, tryptophan, and follows two-enzymatic steps. First, a hydroxyl group is added by tryptophan 5-hydroxylase (TPH; EC: 1.14.16.4) to generate 5-hydroxytryptophan. Mammals produce two TPH enzymes encoded by two independent genes, TPH1 and TPH2. While TPH1 is expressed in peripheral tissues, TPH2 is exclusively expressed in the central nervous system [87-89]. After this hydroxylation step, a carboxyl group is removed by an aromatic Lamino acid decarboxylase (DDC; EC: 4.1.1.28) generating 5HT [90-92].

3.1.2. Catabolism. Within the immune system, four catabolic pathways for the breakdown of 5-HT have been observed. One pathway begins with the generation of melatonin from 5-HT through two enzymatic steps; first, 5-HT is acetylated by arylalkylamine N-Acetyltransferase (AANAT; EC: 2.3.1.87) generating $\mathrm{N}$-acetyl 5-HT, which then acquires a methyl group from $\mathrm{N}$-acetylserotonin-O-methyltransferase (ASMT; EC: 2.1.1.4; previously known as hydroxyndole-Omethyltransferase, HIOMT) to become melatonin [93, 94]. Subsequently, the enzyme indoleamine 2,3-dioxygenase (IDO1 \& IDO2; EC: 1.13.11.52) can convert melatonin into a cyclooxygenase (COX; EC: 1.14.99.1) inhibitor called formyl-N-acetyl-5-methoxykynurenamine. Interestingly this 


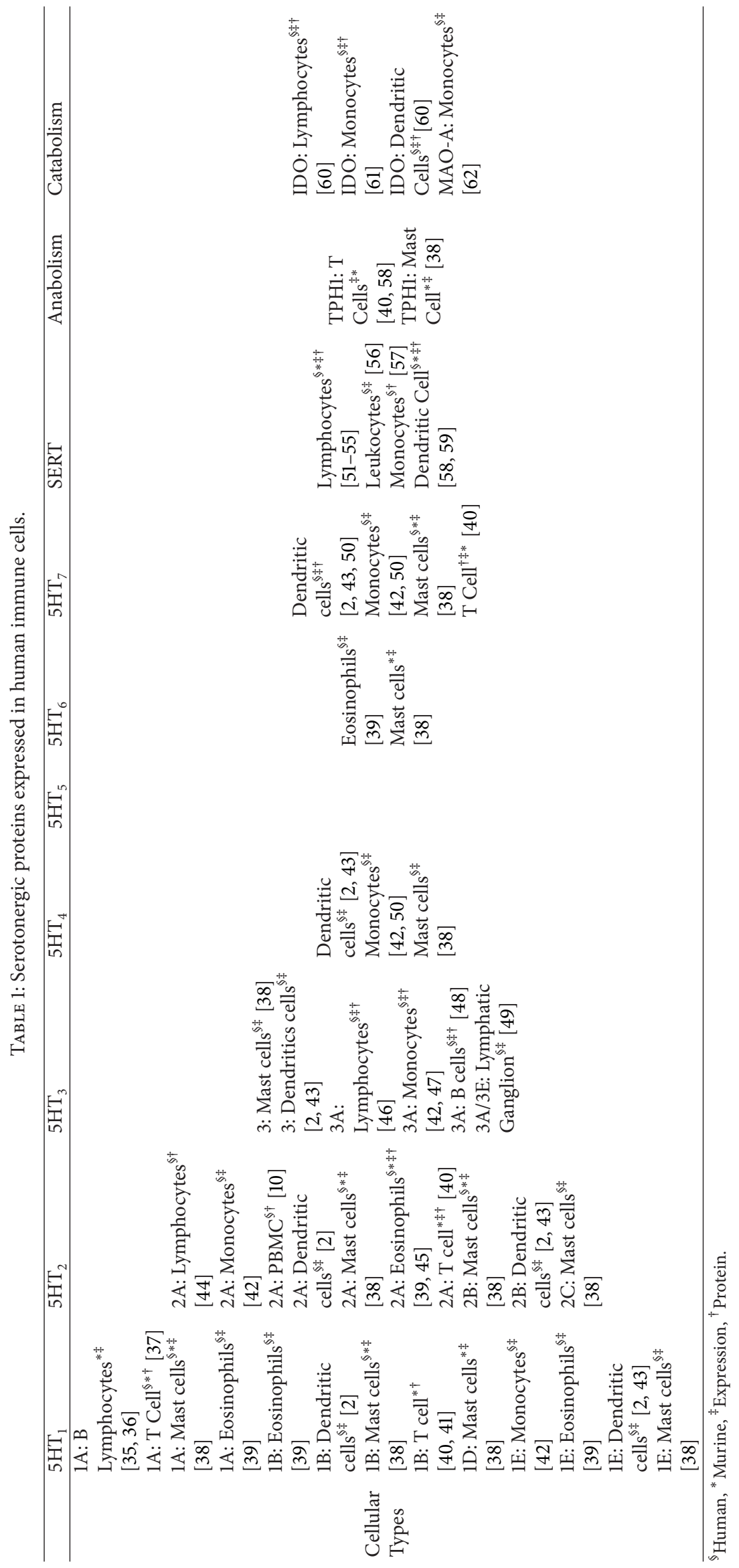




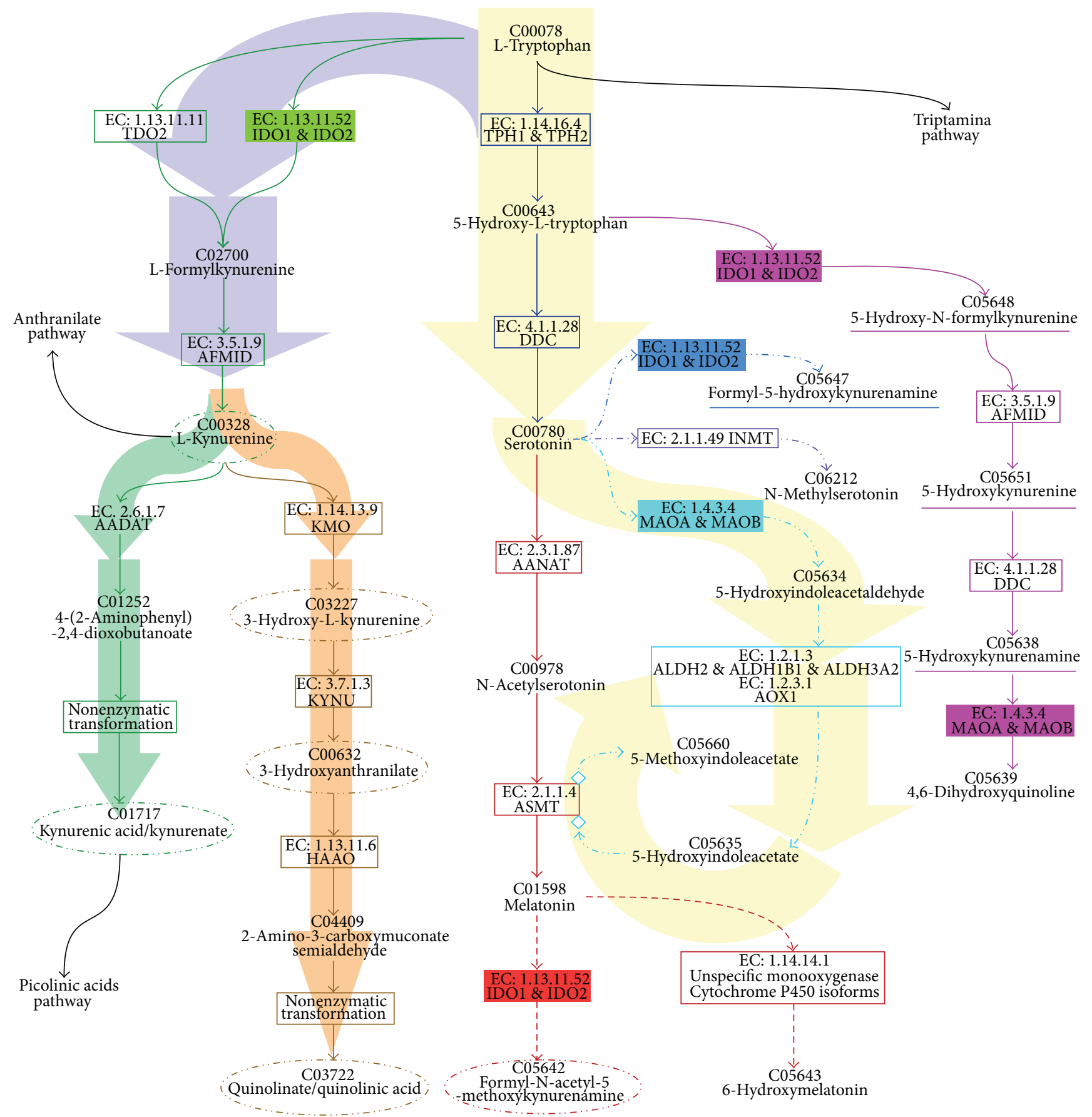

FIGURE 1: Metabolic pathways associated with 5-HT. The metabolic pathways branching from the catabolism of tryptophan are shown. Green and brown branches show kynurenine pathways from tryptophan. The dark blue branch displays the 5-HT generation pathway while the red branch displays the melatonin generation pathway (solid line) and the melatonin catabolism pathway (dashed lines). The 5HT catabolism pathways are depicted in blue, purple, and cyan dotted lines. The most relevant compounds are circled with dotted lines and underlined compounds have no demonstrated effects. An additional catabolic pathway marked in pink from 5-hydroxy-L-tryptophan generates 5-hydroxy-kynurenine and 5-hidroxy-kynurenamine family compounds (paths C05648 and C05647), which have no demonstrated biological effects. The compounds in these pathways are denoted by their "Kyoto Encyclopedia of Genes and Genomes" (KEGG) code (http://www.genome.jp/kegg/). Enzymes with their classification codes (EC, http://www.chem.qmul.ac.uk/iubmb/enzyme/) and UNIPROT gene names are shown in squares. The shading arrows show the most studied pathways. 
metabolite can function to block the synthesis of prostaglandins [95], yet other melatonin metabolites, including 5methoxyindole acetic acid and 6-hydroxymelatonin, have no reported function [96].

A second catabolic pathway of 5-HT utilizes the enzyme indoleamine 2,3-dioxygenase (IDO) and generates formyl5-hydroxykynurenamine. In a third pathway, 5-HT is transformed into 5-hydroxyindoleacetic acid with monoamine oxidase A/B (MAO-A o MAO-B; EC: 1.4.3.4) among other enzymes. Interestingly, MAO-A expression, which is regulated by the cytokines IL- 4 and IL-3, has been identified in human monocytes from peripheral blood [62]. A fourth catabolic pathway generates $\mathrm{N}$-methylserotonin from $5-\mathrm{HT}$ using the enzyme amine N-methyltransferase (INMT; EC 2.1.1.49) and may also be active in immune cells.

It is not thoroughly understood that the extent by which the byproducts and metabolites generated during catabolism may affect the immune system $[1,84]$. The identification of additional 5-HT metabolites in plasma, including serotoninO-sulfate [97] and 5-hydroxykynurenamine [98], suggests that other catabolic pathways linked to specific biochemical processes, such as activation and cell proliferation, may also be associated with the modulation of the immune system.

One additional catabolic pathway related with the four previously described utilizes the enzyme IDO to generate kynurenines from tryptophan. This pathway is positively regulated when immune cells become activated and begin secreting IFN- $\alpha$, IFN- $\beta$ e IFN- $\gamma$, TNF- $\alpha$, TGF- $\beta$, IL- $1 \beta$, and IL-2 $[85,99-101]$, which significantly consumes tryptophan and limits its availability for 5-HT production. L-kynurenine, 3-hydroxy-L-Kynurenine, and 3-hydroxyanthranilic acid can negatively modulate immune responses. Specifically, Vécsei and coworkers noted the blockage of cell proliferation as well as the potential induction of apoptosis in Thl and NK cells [85, 101-103].

It was recently proposed that 5-hydroxyindole thiazolidine carboxylic acid, a 5-HT byproduct found in the intestinal tissues and several brain regions of rats, is generated from the condensation of 5-hydroxyindole acetaldehyde and L-cysteine by a carbon-sulfur lyase (EC 4.4.1.). However, evidence supporting this enzymatic condensation remains to be confirmed. In addition the properties of this byproduct or its potential influence over immunological cells remain to be investigated [104].

3.2. 5-HT Receptors: (5HTR). 5-HT modulates many leukocyte functions ranging from activation of the immune response to memory cell generation. The effects mediated by 5-HT are dependent on the differential expression of serotonergic components in leukocytes. For example, serotonin receptors (5HTR) on immune cells influence cytokine proliferation, delivery, migration, and cellular activation. Signaling through the 5HTR affects chemoattraction in immature mammalian dendritic cells (human and rodent) but not in mature cells, which respond to 5-HT by secreting IL-6 [43]. In addition, 5HTR signaling influences naïve $\mathrm{T}$ cell activation in mice by activating $5 \mathrm{HT}_{7}[40]$ and regulates lymphocyte $\mathrm{B}$ cell proliferation through $5 \mathrm{HT}_{1 \mathrm{~A}}$ [41].
3.2.1. 5HTR Are G Protein-Coupled Receptors (GPCR). The 5HTR belong to the GPCR family class A, also known as 7transmembrane domain (7TM) receptors. GPCR are classified into 6 classes according to a database from the International Union of Basic and Clinical Pharmacology (IUPHAR: http://www.guidetopharmacology.org/) [105]. This system includes classes A, B, and C, as well as the adhesion, Frizzled, and other 7TM classes. Receptors for adenosine, adrenaline/ noradrenaline, $5 \mathrm{HT}_{1}, 5 \mathrm{HT}_{2}, 5 \mathrm{HT}_{4}, 5 \mathrm{HT}_{5}, 5 \mathrm{HT}_{6}$, and $5 \mathrm{HT}_{7}$ all belong to GPCR class A. Furthermore, the 5HTRs are comprised of 6 families and 13 subfamilies [106] with an undetermined number of isoforms that may be produced by alternative splicing. This receptor diversity suggests that a great amount of functional variation may exist between the 5HTRs [107].

Signal transduction from 5HTR is similar to standard GPCRs. $G$ proteins form heterotrimeric complexes made of the subunits $G \alpha, G \beta$ and $G \gamma$; the complex is coupled to the Cterminus of the transmembrane 5HTR. Different subtypes of the $\mathrm{G} \alpha$ proteins $\left(\mathrm{G} \alpha_{\mathrm{i} / \mathrm{o}}, \mathrm{G} \alpha_{\mathrm{s}}\right.$, or $\left.\mathrm{G} \alpha_{\mathrm{q} 11}\right)$ may generate different transduction responses functioning either as activators or inhibitors. When the 5-HT ligand binds its receptor to induce signal transduction it elicits a conformational change in the receptor to facilitate activity [81]. Signal transduction can be carried out by the effector proteins $\mathrm{G} \alpha$ or the heterodimer $\mathrm{G} \beta-\mathrm{G} \gamma$. While transduction mechanisms have been better depicted for $\mathrm{G} \alpha$, especially in cells of the nervous system [108], recent work has been devoted to the role of $\mathrm{G} \alpha$ and $\mathrm{G} \beta$ $\mathrm{G} \gamma$ in the immune system $[109,110]$.

In the last few years, a number of investigations have demonstrated that GPCR are capable of assembling dimers (homo and heterodimers) as well as oligomers. Receptors $5 \mathrm{HT}_{1 \mathrm{~B}}$ and $5 \mathrm{HT}_{1 \mathrm{D}}$ can assembly into homodimers and heterodimers when coexpressed in the same cell. Notably, the receptors display roughly $77 \%$ sequence identity within the 7TM domain [111]. The $5 \mathrm{HT}_{2 \mathrm{C}}$ receptors form homodimers within the cellular membrane [112-114] and it has been proposed that signaling is initiated when two 5-HT molecules bind the dimer [115]. However, activation a single subunit within the $5 \mathrm{HT}_{4}$ homodimer is sufficient to initiate $\mathrm{G}$ protein activation even though simultaneous activation of both receptors doubles the activation efficiency of the pathway. While it appears that 5HTR tend to form homodimers rather than heterodimers, the latter possibility has not been discarded [116].

Milligan and coworkers have postulated that the formation of heterodimers could generate specificity between 5HTR and its substrates, which could be especially relevant for the use and design of pharmacological agents [117]. Despite current knowledge suggesting that the 5-HT receptors function as homodimers and maybe heterodimers, it is possible that higher subunit organizations (e.g., trimers and tetramers) could function under certain circumstances $[114,118]$.

To better understand 5-HT cellular-mediated processes, it will be necessary to characterize the quaternary structure and stoichiometry of 5HTR during oligomerization in regular cellular processes. It will also be important to determine the biochemical details of the quaternary transitional structure 
(quinary structure) of 5HTR to establish not only its functional characteristics, but also the coupling and assembly with cytoskeleton proteins. Recently, the crystal structures of the receptor-agonist complexes, $5 \mathrm{HT}_{1 \mathrm{~B}}$ and $5 \mathrm{HT}_{2 \mathrm{~B}}$ with ergotamine and dihydroergotamina, respectively, were reported and provided structural information to better understand receptor-ligand interactions and agonist selectivity, which could inform 5HTR-based drug design $[119,120]$.

3.2.2. The $5 \mathrm{HT}_{3}$ Receptors Form a Cationic Channel. The $5 \mathrm{HT}_{3}$ receptors are part of a cation-selective ion channel Cys-loop superfamily and have been detected in $\mathrm{T}$ lymphocytes, monocytes [47], mature dendritic cells [43], and mast cells [38]. The functional unit of $5 \mathrm{HT}_{3}$, a pentameric ring, generates a central ion channel and can be composed of two $5 \mathrm{HT}_{3 \mathrm{~A}}$ and three $5 \mathrm{HT}_{3 \mathrm{~B}}$ subunits $[121,122]$. Each subunit contains a large N-terminal domain with the 5-HT binding site and four transmembrane domains connected with intracellular and extracellular loops [123-125]. The $5 \mathrm{HT}_{3}$ receptors are regulated through protein modifications and cytoskeletal rearrangements, dependent on protein kinases (A and C) and F-actin, respectively $[123,126]$.

There are a number of $5 \mathrm{HT}_{3}$ receptor variants that can be expressed from the human genome. The genes encoding $5 \mathrm{HT}_{3 \mathrm{~A}}$ and $5 \mathrm{HT}_{3 \mathrm{~B}}$ are located on chromosome 11q23, and those encoding $5 \mathrm{HT}_{3 \mathrm{C}}, 5 \mathrm{HT}_{3 \mathrm{D}}$, and $5 \mathrm{HT}_{3 \mathrm{E}}$ are on chromosome 3q27. However, the total number of isoforms generated from these genes by alternative splicing has yet to be determined [127-130]. Interestingly, the subunits $5 \mathrm{HT}_{3 \mathrm{C}}, 5 \mathrm{HT}_{3 \mathrm{D}}$, $5 \mathrm{HT}_{3 \mathrm{E}}$, and $5 \mathrm{HT}_{3 \mathrm{Ea}}$ are not sufficient to form functional pentamers but can generate them with $5 \mathrm{HT}_{3 \mathrm{~A}}$ and hence modify 5-HT responses [131].

In the context of the central nervous system, $5 \mathrm{HT}_{3}$ receptors are associated with rapid activation and inhibition responses in addition to fast cellular depolarization $[49,132]$. The cellular depolarization response is unique to neurons, as this has not been observed in immune cells. In neurons, $5 \mathrm{HT}_{3}$ receptors modulate the delivery of neurotransmitters, such as dopamine [133], whereas the same receptors elicit the release of cytokines from immune cells. Human lymph nodes preferentially express the $5 \mathrm{HT}_{3 \mathrm{~A}}$ and $5 \mathrm{HT}_{3 \mathrm{E}}$ variants [49]. In addition, $5 \mathrm{HT}_{3 \mathrm{~A}}$ is expressed in naive and activated B-lymphocytes [48], T lymphocytes, and human monocytes, but expression has not been detected from monocyte-derived dendritic cells [47]. Inhibiting the $5 \mathrm{HT}_{3}$ receptors with antagonists, such as ondasetron and tropisentrol, disrupts TNF- $\alpha$ and IL- $1 \beta$ production, suggesting that these receptors may activate the p38/MAPK pathway $[134,135]$.

3.3. SERT: 5-HT Transporter. The serotonin transporter SERT actively moves extracellular 5-HT across the plasma membrane into the cell. The transporter is also known as solute carrier family 6, member 4 (SLC6A4), and belongs to a family of neurotransmitters with 12 transmembrane domains. The function of SERT in platelets is critical for maintaining adequate 5-HT concentrations in the circulatory system [136]. To function, SERT depends on the transport of $\mathrm{Na}^{+} / \mathrm{Cl}^{-}$ions, yet the coordinated mechanism of $5-\mathrm{HT}$ and ion transport remains to be elucidated.
The gene encoding SERT has 14 exons and is located on chromosome 17q11.1-17q12. Two genetic polymorphisms in the gene regulatory region modulate transcription generating a complex mix of long and short variants [137]. The SERT functional unit is a dimer but it has been suggested that two SERT homodimers could assemble into a tetramer [138]. Other members of the protein family form heterodimers; however, these may not be functional [139]. Therefore, SERT homodimers are currently accepted as the biochemically functional unit.

SERT dimer formation relies on several posttranslational modifications. The SERT proteins are glycosylated, and then sialic acid is inserted into each of two N-linked glycans. In the absence of glycosylation, the functional activity of SERT is reduced. Furthermore, the addition of sialic acid molecules is important for dimer formation and the association with myosin IIA (a kinase that anchors protein kinase G, PKG) at the cytoskeleton. This association can regulate SERT phosphorylation by the guanosine monophosphatedependent PKG [140].

A complex regulatory mechanism of SERT internalization associated with the cytoskeleton has been described in platelets and is referred to as serotonylation (see Box 1). The process of serotonylation depends on the 5-HT gradient between the extracelluar and intracellular space created by SERT activity. The gradient mediates regulation via cytoskeletal components, vimentin, 5HTR, SERT, small GTPases, transglutaminases (TGases), and possibly p21 activated kinases (p21/PAK) [141]. Specifically, increased levels of 5-HT activate SERT internalization through activation of small GTPases by serotonylation (TGases covalently linking the 5-HT to the small GTPases). Currently efforts are being directed to the characterization of SERT internalization mechanisms in leukocytes.

Box 1 (serotonylation: SERT, TGasas, and small GTPases). Serotonylation is the process by which 5-HT is covalently bound to a protein through a transamination reaction and constitutes a mechanism for regulating signal transduction. This process requires high intracellular levels of 5- $\mathrm{HT}$ and is mediated by transglutaminases (TGases. EC: 2.3.2.13). Physiological serotonylation has been demonstrated in platelets and other cells $[142,143]$ but not in leukocytes. However, serotonylation may be involved in specific leukocyte functions required for chemotaxis or cytokine secretion [43, 45] because this modification regulates similar functions in platelets and pancreatic beta cells.

Although many cytoplasmic proteins can be serotonylated, the effect of serotonylation on small GTPases during platelet activation and aggregation is noteworthy [142]. Serotonylation induces constitutive RhoA activation and, consequently, the cytoskeletal reorganization needed for aggregation [144-147]. Increased intracellular $\mathrm{Ca}^{2+}$ and 5-HT in platelets also activates Rab4-mediated exocytosis of alpha granules by $\mathrm{Ca}^{2+}$-dependent TGase-mediated serotonylation [142].

In pancreatic beta cells, Rab3a and Rab27a are serotonylated during insulin exocytosis [143]. In smooth muscle cells TGase-2-mediated serotonylation of RhoA may be required 
for proliferation [148-150]. Furthermore, serotonylation of RhoA not only constitutively activates it, but also increases its rate of proteosomal degradation [148]. Since Rab27a and Rab27b also participate in exocytosis from platelets and endocrine cells [151-155], these processes may be also susceptible to serotonylation.

Additionally, 5-HT induces vimentin filament reorientation around SERT [156]. Furthermore, serotonylation of Rab4 promotes interaction with the SERT C-terminal domain regulating translocation [157]. Importantly, there are no reports that specifically study serotonylation in leucocytes, but available information suggests that it may regulate cytoskeletal reorganization in these cells $[43,45]$. Rab27a is expressed in cytotoxic $\mathrm{T}$ cells and regulates the last step of granular exocytosis $[158,159]$. Rab27, RhoA, and Rab4 are also expressed in several cells of the immune system [160-162]; therefore it is possible that serotonylation regulates exocytosis or cytoskeletal reorganization during functions such as MHC presentation.

3.4. 5-HT Storage and Exocytosis in Leukocytes. Three potential outcomes may take place following 5-HT internalization: signaling may be activated by serotonylation, 5-HT may undergo enzymatic transformation, or 5-HT may be stored in specialized vesicles. The synthesis, storage, and transport of 5-HT in the immune system are more diverse and complex than previously reported, and a seminal review of the subject was recently published by Ahern in 2011 [163].

Storage of 5-HT in the immune system allows for its reuse by exocytosis, which occurs in dendritic cells, peripheral blood lymphocytes, and platelets. Within these cells, the vesicular monoamine transporter (VMAT) is responsible for storing 5-HT inside dense granules [164]. The 5-HT transport and storage/exocytosis pathways in platelets are coupled to the serotonylation signaling pathway, which assesses 5-HT concentrations and dictates its fate [165]. LAMP1 containing vesicles in monocyte-derived dendritic cells from mice also store 5-HT, and upon ATP stimulation $\left(\mathrm{Ca}^{2+}\right.$ influx), these cells secrete 5-HT and cytokines [58]. A major focus of current endeavors is the investigation of several 5-HT mediated processes in other types of leukocytes, including 5-HT vesicle storage, small GTPases-mediated serotonylation, cytoskeletal associations, and the metabolism of 5-HT into derivatives, such as melatonin and kynurenins.

\section{The Effects of 5-HT on Leukocytes}

Innate and adaptive immune responses rely on a diverse set of cell types from lymphoid linage (T cells, B cells, and NK cells), myeloid linage (neutrophils, eosinophils, basophils, monocytes, and mast cells), or myeloid/lymphoid linage (dendritic cells) origins. Professional antigen presenting cells (APC), such as dendritic cells and macrophages, link the innate and adaptive immune responses by recognizing, processing, and presenting antigens on MHC-II. Antigen presentation activates naïve $\mathrm{T}$ cells initiating clonal proliferation and generating the immune memory, which is essential for the adaptive phase of an immune response.
The local concentration of 5-HT can modulate a number of events during these immune responses [10]. One reason immune cells respond to 5-HT is that, as mentioned previously, they constitutively express the molecular machinery that constitutes the serotonergic system.

4.1. Neutrophils. Neutrophils, the most abundant innate immune cells in human blood, constitute a first line of defense against infection by recognizing foreign antigens, producing antimicrobial compounds, and secreting cytokines and chemokines to recruit immunocompetent cells [166]. Mouse models have demonstrated that neutrophil recruitment to sites of acute inflammation requires platelet-derived chemotactic stimuli, such as 5-HT, PAF (platelet-activation factor), and histamine $[167,168]$.

4.2. Monocytes/Macrophages. Macrophages as well as their precursors, circulating monocytes, participate in immune responses during pathogen infection. Monocytes can be divided in two subsets: those that express CD14, a component of the lipopolysaccharide (LPS) receptor complex, and those that express CD16, the Fc $\gamma$ RIII immunoglobulin receptor $[169,170]$. CD14+ cells, which constitute $80-90 \%$ of the circulating monocytes, express $5 \mathrm{HT}_{1 \mathrm{E}}, 5 \mathrm{HT}_{2 \mathrm{~A}}, 5 \mathrm{HT}_{3}, 5 \mathrm{HT}_{4}$, and $5 \mathrm{HT}_{7}$ mRNAs [42]. LPS stimulation does not affect 5HTR expression suggesting that the receptors constitutively regulate cell functions.

The addition of 5-HT to monocytes induces phagocytosis of opsonized goat erythrocytes [171]. However, 5-HT has been noted to elicit a number of responses in CD14+ cells isolated from peripheral blood of healthy subjects [42]: (i) 5HT signaling decreases TNF- $\alpha$ secretion in a dose-dependent manner; (ii) 5-HT signaling enhances LPS-induced secretion IL-12p40 from activated monocytes, which acts as a chemoattractant for macrophages and promotes the migration of bacterially stimulated dendritic cells; and (iii) 5 -HT signaling enhances LPS-induced secretion of IL-6, IL-1 $\beta$, IL-8/CXCL8. The first two effects are mediated by the $5 \mathrm{HT}_{4}$ and $5 \mathrm{HT}_{7}$ receptors, whereas the third effect requires $5 \mathrm{HT}_{3}, 5 \mathrm{HT}_{4}$, or $5 \mathrm{HT}_{7}$.

Macrophages also respond to 5-HT although reports conflict as to whether the response is inhibitory or stimulatory and the mechanisms involved have yet to be clearly described. For example, combined stimulation with 5-HT and muramyl peptides induces superoxide secretion by peritoneal macrophages [172]. Bovine alveolar macrophages release chemotactic factors for neutrophils and monocytes in response to 5-HT and histamine [173]. Similarly, murine macrophages detect 5-HT with the $5 \mathrm{HT}_{2 \mathrm{C}}$ receptor to induce the secretion of CCL2, which induces monocyte migration [174]. In peritoneal murine macrophages $5-\mathrm{HT}$ induces phagocytosis in a dose-dependent manner through $5 \mathrm{HT}_{1 \mathrm{~A}}$ and $\mathrm{NF} \mathcal{K}$-B activation [175].

On the other hand, $5-\mathrm{HT}$ is also reported to function as negative regulator. For example, $5-\mathrm{HT}_{2}$ signaling limited the activation of murine macrophages stimulated in vitro with high concentrations of IFN- $\gamma$ [176]. Furthermore, human alveolar macrophages stimulated with LPS and 5-HT secreted less TNF- $\alpha$ and IL-12, but more IL-10, nitric oxide, and 
prostangladin-E2. However, the receptors mediating these effects have yet to be described [177].

The different macrophage responses elicited by 5 -HT may be due to phenotypic differences in tissue-specific macrophages (i.e., changes in the proportion of 5-HT receptors) or the effect of cooperative signaling with other molecules [178]. Finally, macrophages can rapidly metabolize $5-\mathrm{HT}$ to $5-$ hydroxyindole acetic acid [179], a biotransformation pathway that may be mediated by MAO-A/B, ALDH/AOX and ASMT, which could affect serotonergic responses in these cells.

4.3. Dendritic Cells (DCs). DCs play a crucial role in the immune response to infectious pathogens. In humans, circulating DCs characteristically expresses high levels of class II HLA molecules and are proficient in antigen uptake and processing. However, they express low levels of HLA class I and costimulatory molecules, such as CD80 and CD86, and lack common lineage markers such as CD3, CD14, CD16, CD19, CD20, and CD56. DCs are positioned between the adaptive and innate immune systems: detecting microbial infection, tissue damage, and inflammatory signals to promote the activation of antigen-specific responses [180-182].

Peripheral blood monocytes can differentiate into macrophages or DCs depending on environmental stimuli. Culturing cells with IL-4 and granulocyte-macrophage colonystimulating factor (GM-CSF) induces human monocytes and murine myeloid progenitors to differentiate into monocytederived dendritic cells (MDDCs) and bone marrow dendritic cells (BMDCs), respectively. These cells, frequently used as models for dendritic cell biology [50,58, 183], are sensitive to LPS and 5-HT (Table 2).

When 5-HT is added during IL-4/GM-CSF differentiation, the resulting MDDCs display lower levels of CD1a, CD86, and HLA-DR but had increased CD14 expression. However, other markers such as CD40, CD80, or CD83 were unaffected. Murine BMDCs can be matured by LPS stimulation to generate cells with characteristics of DCs [184]. Although immature (CD11c+CD86-) and mature (CD11c+CD86+) BMDCs constitutively express SERT, maturation induced by LPS increases SERT expression and, consequently, mature BMDCs have an increased capability for intake, storage, and exocytosis of 5-HT [58]. BMDC maturation also reduces the expression of enzymes involved in the metabolism of 5-HT, such as MAO-A and -B. Furthermore, immature and mature dendritic-like cells respond differently to 5-HT [50]. In mature MDDCs, the $5 \mathrm{HT}_{3}$ receptor contributes to changes in intracellular $\mathrm{Ca}^{2+}$ concentration required for the secretion of IL- 8 and IL-1 $\beta$ [2]. On the other hand, 5-HT inhibits CXCL10 secretion from mature MDDC, but CCL22 secretion is not affected [43].

Additionally, 5-HT can regulate MDDC functional responses. Costimulation with 5-HT and LPS induces immature MDDCs migration in a $5 \mathrm{HT}_{1 \mathrm{~B}}$ and $5 \mathrm{HT}_{2 \mathrm{~A}}$-dependent manner. However, if 5-HT is added subsequent to LPSmediated maturation, migration is unaffected but cytokine and chemokine secretion is induced [43]. Additional in vitro experiments with MDDCs and BMDCs have also demonstrated that 5-HT activates the secretion of pro-inflammatory cytokines $[2,185]$.
TABLE 2: The effect of 5-HT on MDDC cytokine production.

\begin{tabular}{|c|c|c|}
\hline Cytokine secretion & 5-HT receptors involved & References \\
\hline$\uparrow$ IL-6 & $5 \mathrm{HT}_{3}, 5 \mathrm{HT}_{4}$ and $5 \mathrm{HT}_{7}$ & $\begin{array}{l}\text { Müller et al., } \\
2009 \text { [43] }\end{array}$ \\
\hline$\downarrow$ IL-12p70 & $5 \mathrm{HT}_{4}$ and $5 \mathrm{HT}_{7}$ & $\begin{array}{l}\text { Müller et al., } \\
2009 \text { [43] }\end{array}$ \\
\hline$\uparrow \mathrm{IL}-10$ & $5 \mathrm{HT}_{4}$ and $5 \mathrm{HT}_{7}$ & $\begin{array}{l}\text { Müller et al., } \\
2009 \text { [43] }\end{array}$ \\
\hline $\begin{array}{l}\uparrow \text { IL-8, IL-1 } \beta \\
\downarrow \text { IL-12, TNF- } \alpha\end{array}$ & $\begin{array}{c}5 \mathrm{HT}_{3}, 5 \mathrm{HT}_{4} \\
\text { (G } \alpha \mathrm{s}-\text { coupled), and } \\
\text { 5HTR7 (G } \alpha \text { s-coupled) }\end{array}$ & $\begin{array}{l}\text { Idzko et al., } \\
2004 \text { [2] }\end{array}$ \\
\hline
\end{tabular}

One key DC function is the activation of T cells and 5-HT can also regulate this fundamental immunological process. Since dendritic-like cells do not express TPH1, it is unlikely that they can synthetize 5-HT. Therefore, O'Connell and coworkers postulated that SERT-expressing DCs are able to internalize 5-HT from the microenvironment [58]. When interacting with $\mathrm{T}$ cells, MDDCs transiently release $\mathrm{Ca}^{2+}$, which promotes cytokine and 5-HT secretion from LAMP1+ vesicles [186]. Thus, DCs may internalize and store 5-HT to release into the immunological synapse during $\mathrm{T}$ cell activation [58]. Activated T cells express TPH1 [58] and therefore, can synthetize 5-HT. The synthesis of 5-HT in activated T cells is related to tryptophan metabolism [40] and may also be important when $\mathrm{T}$ cells interact with target cells [43].

Taken together, 5-HT affects DC differentiation and maturation as well as the profile and function of soluble mediators these cells express. Thus, 5-HT may participate in the generation of a specific subset of DCs with unique immunomodulatory properties [50].

4.4. T Cells. Differentiation, proliferation, and the functional responses of $\mathrm{T}$ cells can each be modulated by the serotonergic system. Based on experiments using the cell line K562, 5-HT participates in T cell maturation in lymphoid organs in a $\mathrm{Na}^{+}$-coupled, 5-HT active transport-dependent manner (presumably SERT), which requires intracellular $\mathrm{Ca}^{2+}$ changes [187].

Based on the effects of 5-HT receptor-specific agonists or antagonists, $\mathrm{T}$ cell proliferation and secretion of proinflammatory cytokines, such as IL- 2 and IFN- $\gamma$, requires activation of $5 \mathrm{HT}_{1 \mathrm{~A}}$ but not $5 \mathrm{HT}_{1 \mathrm{C}}$ [37]. Naïve $\mathrm{T}$ cells primarily express $5 \mathrm{HT}_{7}$ and low levels of TPH1, but they do not express $5 \mathrm{HT}_{1 \mathrm{~B}}$ or SERT. After 5-HT stimulation, the ERK-1,-2/NF$\kappa \mathrm{B}$ pathway is activated in proliferating $\mathrm{T}$ cells, and they express $5 \mathrm{HT}_{1 \mathrm{~B}}, 5 \mathrm{HT}_{7}, 5 \mathrm{HT}_{2 \mathrm{~A}}$, and $\mathrm{TPH}$ [40]. In activated human $\mathrm{CD} 4+\mathrm{T}$ cells, 5 -HT or $5 \mathrm{HT}_{3}$ specific agonists impair migration towards CXCL12 gradients, but not to those of CCL2 or CCL5, which control T cell migration into tissues. However, immature murine CD4+ $\mathrm{T}$ cells do not express $5 \mathrm{HT}_{3}$, and 5-HT does not affect cell migration. But, activation of these cells induces the expression of $5 \mathrm{HT}_{3 \mathrm{~A}}$ [46] suggesting they may respond to 5 -HT once activated.

Therefore, the $\mathrm{T}$ cell activation state and environment may influence the effects of 5-HT. For example, 5-HT inhibits 
phytohemagglutinin- (PHA-) mediated lymphocyte proliferation, possibly through reduced expression and distribution of the IL-2 receptor [188, 189]. In addition, concanavalin A (ConA) and low concentrations of 5-HT increased murine $\mathrm{T}$ cell proliferation although the activation of $\mathrm{CD} 4+$ and CD8+ subsets was reduced [190, 191]. This demonstrates that 5-HT elicited effects are concentration dependent and suggests: (i) 5-HT induces dose-dependent phenotypes, (ii) differentiation may be achieved by receptors with different 5-HT affinity, and (iii) local 5-HT concentrations are tightly regulated to induce specific effects.

T cells express SERT and, therefore, can acquire 5-HT $[51,52,192,193]$. However, naïve T cells have reduced SERT functional activity [164] and may result to 5-HT synthesis. In agreement with this hypothesis, a report from Aune and coworkers demonstrates that the inhibition of the 5-HT synthesis in IL-2-stimulated T cells blocks cell proliferation. The addition of 5-hydroxtriptophan, a 5-HT precursor, restores proliferation, further suggesting that these cells synthesize the molecule rather than acquire it [37]. However, further research is required to understand how 5-HT synthesis is regulated in T cells.

4.5. B Cells. B cells recognize circulating antigen; as a consequence, they activate processes that end in the generation of memory B cells or antibody-forming plasma cells [194]. 5$\mathrm{HT}$ increases the proliferation of murine B cells by activating $5 \mathrm{HT}_{1 \mathrm{~A}}$ [41]. In addition, SERT expression is proportional to the proliferation rates of human leukemic B cells. Specifically, SERT-specific inhibitors, such as fluoxetine, fenfluramine, or 3,4-methylenedioxymethamphetamine (MDMA), elicited anti-proliferative and pro-apoptotic effects [195].

4.6. NK Cells. NK cells recognize antigen in the context of CD1 controlling viral replication early in infection and inhibiting the development of cancer [196, 197]. These cells are inhibited with oxidation produced by autologous monocytes and with apoptosis induced by reactive oxygen species (ROS); however, 5-HT signaling limits these forms of inhibition [198]. NK cells express $5-\mathrm{HT}_{1 \mathrm{~A}}$ and therefore can sense 5-HT local concentration [199-202]. In fact, $5 \mathrm{HT}_{1 \mathrm{~A}}$-specific antagonists, such as pindobind, exacerbate the inhibitory effect of monocyte-mediated ROS production on NK cells [202].

4.7. Eosinophils. Eosinophils are responsible for fighting multicellular parasites and other infections in vertebrates; they also control mechanisms associated with allergy and asthma. Eosinophils express the 5- $\mathrm{HT}$ receptors $5 \mathrm{HT}_{1 \mathrm{~A}}, 5 \mathrm{HT}_{1 \mathrm{~B}}$, $5 \mathrm{HT}_{1 \mathrm{E}}, 5 \mathrm{HT}_{2 \mathrm{~A}}$, and $5 \mathrm{HT}_{6}$, but they do not express $5 \mathrm{HT}_{2 \mathrm{C}}$, $5 \mathrm{HT}_{3}, 5 \mathrm{HT}_{4}$, and $5 \mathrm{HT}_{7}$. However, differential expression of $5 \mathrm{HT}_{2 \mathrm{~A}}$ was detected in allergy and asthma patients [39].

The serum levels of 5-HT are higher in symptomatic asthma patients in comparison to asymptomatic patients, which may influence eosinophil-mediated inflammation in patients with active disease. 5-HT is a potent chemoattractant for eosinophils both in vivo and in vitro and supports rolling, an important feature of these cells. Antagonists of $5 \mathrm{HT}_{2 \mathrm{~A}}$ inhibit both effects suggesting that 5-HT mediates eosinophil activation [45]. Migration and rolling require changes in the actin cytoskeleton and activation of PKC and calmodulin signaling [39, 45], which control the morphological changes required for eosinophil infiltration from circulation to sits of inflammation [39].

4.8. Basophils. While basophils represent less than $2 \%$ of leukocytes, they actively participate in immune responses in peripheral organs where they are recruited during nematode and ectoparasite infections. They also participate in allergic reactions by releasing histamine in response to specific growth factors, such as IL-3 [203, 204]. In addition, basophils are an important source of IL- 4 and therefore may promote Th2 differentiation $[205,206]$.

The role of 5-HT on basophil functions has not been clarified. Murine basophil exposure to 5-HT inhibits IL-4 secretion in a dose-dependent manner both in vitro and in vivo [204]. 5-HT also blocks the release of histamine, IL-4, and IL-6 from murine basophils following IL-3 stimulation as well as blocking the release of IL-13 and IL-4 from human peripheral blood basophils [204]. Intraperitoneal administration of IL-33 to mice normally increases the serum levels of IL-4, but is blocked by the administration of 5-HT [204]. Although murine basophils express SERT, drugs targeting the transporter, such as fluoxetine or citalopram (Selective Serotonin Reuptake Inhibitor, SSRI), do not block the effect of $5-\mathrm{HT}$ on cytokine release suggesting that other transporters may be used, such as the organic cation transporter 3 [204].

4.9. Mast Cells. Human mast cells play a local regulatory role at the site of inflammation. Human mast cells express $5 \mathrm{HT}_{1 \mathrm{~A}}, 5 \mathrm{HT}_{1 \mathrm{~B}}, 5 \mathrm{HT}_{1 \mathrm{E}}, 5 \mathrm{HT}_{2 \mathrm{~A}}, 5 \mathrm{HT}_{2 \mathrm{~B}}, 5 \mathrm{HT}_{2 \mathrm{C}}, 5 \mathrm{HT}_{3}, 5 \mathrm{HT}_{4}$, and $5 \mathrm{HT}_{7}$. Cell migration and fibronectin adhesion are both influenced by the addition of 5-HT to these cells. Although $5 \mathrm{HT}_{2 \mathrm{~A}}$ is the predominant receptor, responses are primarily mediated through $5 \mathrm{HT}_{1 \mathrm{~A}}$ and can be blocked by the Gprotein inhibitor pertussis toxin [38].

4.10. Platelets. Platelets are well known for initiating coagulation and maintaining vascular tone; however, these cells also participate in inflammatory responses by releasing histamine and PAF. They provide a local source of biogenic amines, including 5-HT, in damaged regions of the vasculature [207]. Platelets uptake 5-HT from plasma in a fast and saturable process; therefore, they are also key regulators of the circulatory 5-HT concentration [164]. The local concentration of 5-HT during platelet aggregation is approximately $100 \mu \mathrm{M}$ [208]. 5HT uptake is mediated by SERT, and once inside the cell it is transported to dense granules by VMAT (Vesicle Monoamine Transporter) or hydrolyzed by MAO [136].

5-HT signaling activates Rab4, which controls alpha granule secretion, and RhoA, which induces the cytoskeletal reorganization required for adhesion and aggregation [144, 145 , 209]. It is reported that Rab4 activation occurs by serotonylation (see Box 1), and it is likely that RhoA is similarly activated.

Increases in the serum levels of 5-HT enhance SERT density on the platelet cell membrane [142, 148, 156, 157]. Some studies suggest that human platelets initiate murine 
TABLE 3: Pathology-associated serotonergic protein expression in immune cells.

\begin{tabular}{|c|c|c|}
\hline Patology/condition & 5-HT, SERT and 5HTR variation & Reference \\
\hline $\begin{array}{l}\text { Major depression disorder } \\
\text { Human }\end{array}$ & $\begin{array}{l}\downarrow \text { SERT in platelets } \\
\downarrow 5 \text {-HT serum levels } \\
\downarrow \text { SERT in lymphocytes }\end{array}$ & $\begin{array}{l}\text { Mössner et al., } 2007[63] \\
\text { Fazzino et al., } 2008[64] \\
\text { Lima and Urbina, 2002 [52] } \\
\text { Peña et al., } 2005[65]\end{array}$ \\
\hline $\begin{array}{l}\text { Fibromyalgia } \\
\text { Human }\end{array}$ & $\begin{array}{l}\downarrow \text { 5-HT serum levels } \\
\downarrow \text { SERT platelets }\end{array}$ & Bazzichi et al., 2006 [66] \\
\hline $\begin{array}{l}\text { Schizophrenia } \\
\text { Human }\end{array}$ & $\begin{array}{l}\uparrow 5 \mathrm{HT}_{2 \mathrm{~A}} \text { (polymorphism T102C) in lymphocytes } \\
\uparrow 5 \mathrm{HT}_{3 \mathrm{~A}} \text { (gene) in PMBC } \\
\downarrow \text { SERT (re-uptake) in lymphocytes }\end{array}$ & $\begin{array}{l}\text { Williams et al., } 1997 \text { [67] } \\
\text { Abdolmaleky et al., 2004 [68] } \\
\text { Shariati et al., 2009 [69] } \\
\text { Marazziti et al., } 2006[70]\end{array}$ \\
\hline $\begin{array}{l}\text { Asthma } \\
\text { Human }\end{array}$ & $\uparrow 5$-HT plasma levels & Lechin et al., 1998 [71] \\
\hline $\begin{array}{l}\text { Alzheimer disease } \\
\text { Human }\end{array}$ & $\begin{array}{l}\uparrow 5 \mathrm{HT}_{2 \mathrm{C}} \text { in NK cells } \\
\downarrow 5 \text {-HT serum levels }\end{array}$ & Martins et al., 2012 [72] \\
\hline $\begin{array}{l}\text { Psoriasis } \\
\text { Human }\end{array}$ & $\uparrow$ SERT of skin biopsies, dendritic cells & Thorslund et al., 2013 [59] \\
\hline $\begin{array}{l}\text { Alcohol exposition } 0.1 \% 24 \mathrm{~h} \\
\text { Culture, dendritic cells }\end{array}$ & $\begin{array}{l}\uparrow \text { SERT in dendritic cells } \\
\downarrow 5 \text {-HT extracellular levels }\end{array}$ & Babu et al., 2009 [73] \\
\hline $\begin{array}{l}\text { Arthritis } \\
\text { Cell culture }\end{array}$ & $\begin{array}{l}\uparrow 5 \mathrm{HT}_{2 \mathrm{~A}} \text { mRNA in macrophage-like synovial cells } \\
\uparrow 5 \mathrm{HT}_{3} \text { mRNA in macrophage-like synovial cells }\end{array}$ & Seidel et al., 2008 [74] \\
\hline $\begin{array}{l}\text { Mitogen activation with concanavalin } \\
\text { Rat lymphocyte }\end{array}$ & $\uparrow 5 \mathrm{HT}_{7} \mathrm{mRNA}$ & Urbina et al., 2014 [75] \\
\hline
\end{tabular}

T cell activation by Fc $\epsilon$ RI-mediated contact sensitivity and the release of 5-HT [207]. However, the functional role that platelet-derived 5-HT plays in the immune system is still far from being fully understood.

\section{Changes to the Serotonergic System Affect Immune Responses and Have Clinical Implications}

Immune cells respond to 5-HT with varying degrees of sensitivity, which can be partially explained by differences in the expression of serotonergic components. In this section, we review how pathologies with reported alterations to the serotonergic system affect the immune system (Table 2). We also discuss the effects of SERT-targeting drugs, such as SSRIs, as well as drugs that target 5-HT receptors (Table 3).

5.1. Diseases Associated with Systemically Low 5-HT Levels. Major depressive disorder (MDD), Fibromyalgia, infections, and Alzheimer's disease commonly display reduced 5-HT serum levels. The precise effects these changes have on the immune system in each disease are poorly defined. However, MDD provides a good example because serotonergic alterations are directly related to the severity of disease.

5.1.1. Major Depressive Disorder (MDD). MDD is defined as a pervasive and persistent low mood with a multi-factor cause. Symptoms have degrees of severity that are associated with changes in both CNS and peripheral 5-HT concentrations [210]. In addition, MDD patients commonly have altered cortisol and cytokine blood levels [210-212]. Lymphocytes from MDD patients express lower levels of SERT in comparison with those from healthy volunteers without changes in the intracellular concentration of 5-HT [52, 64]. There are no changes in SERT expression in monocytes, but the intracellular concentration of 5-HT in monocytes is higher in MDD patients [64]. MDD patient lymphocytes display a three-fold increase in LPS-stimulated proliferation, an effect blocked by $5-\mathrm{HT}_{1}$ antagonists [213]. In addition, there are more $5-\mathrm{HT}_{2 \mathrm{~A}}$ clusters on the lymphocytes of MDD patients, whom are responsive to SSRI treatment [44].

When MDD patients are treated with SSRIs there are changes in lymphocyte subpopulations and in systemic inflammatory mediators (Table 4). Before treatment, MDD patients have higher blood cortisol, IL-4, IL-13, and IL-10 than healthy volunteers [210-212]. After 20 weeks of treatment, concomitantly with a remission of the depressive episode there are increases in IL- 2 and IL- $1 \beta$ but no change in cortisol levels. At week 52 of treatment there is a significant reduction in cortisol levels with an increase in IL- $1 \beta$ and IFN- $\gamma$ and a decrease in anti-inflammatory cytokines [211]. Regarding lymphocyte subpopulations, before SSRI treatment MDD patients had more NK cells compared to healthy volunteers (312 \pm 29 versus $158 \pm 30$; cells $/ \mathrm{mL})$, but no differences were found in the $\mathrm{T}$ and $\mathrm{B}$ cell populations. After 20 weeks of treatment, patients experienced a remission of depressive episodes along with an increase in NK cell and B cell populations, which remained heightened until the 52 nd week of treatment [214]. These findings in conjunction with the fact that lymphocytes from MDD patients respond differently than healthy subjects suggest that the general inflammatory response and specific immune subsets are sensitive to systemic levels of 5-HT and changes in those levels induced 
TABLE 4: Serotonergic drugs and their effects on the immune system.

\begin{tabular}{|c|c|c|}
\hline Pathology/treatment & Result & Reference \\
\hline $\begin{array}{l}\text { HIV chronic infection/ } \\
\text { SSRI (citolopram) } \\
\text { Human }\end{array}$ & $\begin{array}{l}\downarrow \text { Macrophage infectivity } \\
\downarrow \text { Viral replication in macrophages and T cells } \\
\uparrow \text { NK cell activity }\end{array}$ & $\begin{array}{l}\text { Benton et al., } 2010 \text { [57] } \\
\text { Evans et al., } 2008 \text { [76] }\end{array}$ \\
\hline $\begin{array}{l}\text { HCV infection } \\
\text { IFN- } \alpha \text { and SSRI (escitalopram) } \\
\text { Human }\end{array}$ & $\downarrow$ Depression symptoms & Schaefer et al., 2012 [77] \\
\hline $\begin{array}{l}\text { Tendinopathy and facial pain } \\
\text { 5-HT3 antagonist (tropisetron) } \\
\text { Human }\end{array}$ & Analgesic effect & $\begin{array}{l}\text { Müller and Stratz, } 2004 \\
\text { [78] }\end{array}$ \\
\hline $\begin{array}{l}\text { Infection with Leishmania donovani } \\
\text { SSRI (sertraline) } \\
\text { Balb/c mice }\end{array}$ & $\begin{array}{l}\text { SSRI killed } L \text {. donovani promastigotes and intracellular } \\
\text { amastigotes }\end{array}$ & Palit and Ali, 2008 [79] \\
\hline $\begin{array}{l}\text { CT26/luc colon carcinoma-bearing mice } \\
\text { Mirtazapine }\end{array}$ & $\downarrow$ T cell infiltration in tumor & Fang et al., 2012 [80] \\
\hline
\end{tabular}

by SSRIs. However, further studies are still required to fully understand how components of the serotonergic system are differentially expressed on immune cell subsets. This may clarify the mechanisms involved in MDD progression and highlight new therapeutic targets for its treatment.

5.1.2. Fibromyalgia. Fibromyalgia (FM) is a common chronic pain syndrome that primarily affects the joints and muscles and is generally associated with other somatic and psychological symptoms, including fatigue, poor sleep, cognitive difficulties, and stress [214]. FM patients have central sensitization and increasing glial cell activation, which, in turn, favors pain signaling and activates the release of pro-inflammatory cytokines, nitric oxide, prostaglandins, and ROS that sustain the hyperexcitable state of the spinal cord [215-217].

Several neurotransmitters are involved in FM-associated central sensitization. $5-\mathrm{HT}_{2}$ and $5-\mathrm{HT}_{3}$ are involved in pain control, indicating a key participation of the serotonergic system $[218,219]$. Levels of $5-\mathrm{HT}$ are low in the serum and cerebrospinal fluid of FM patients and correlate with clinical symptoms [66, 220-222]. FM patients also have increased B cell and decreased NK cell counts [223]. The administration of the $5-\mathrm{HT}_{3}$ antagonist tropisetron [224] or high doses (45 mg) of the SSRI fluoxetine [225] produce analgesic and/or other beneficial effects in FM patients (Table 4), suggesting that regulation of the serotonergic system can be useful. However, to date it is not known whether the components of the serotonergic system can be altered in the immune cells of patients.

5.1.3. Infections. Immune responses to viruses, bacteria, fungi, and parasites all require 5-HT. Human immunodeficiency virus (HIV) infection is a primary model for the study of 5-HT during infection (Table 4). 5-HT controls HIV replication in T4 lymphocytic cell lines [226] and modulates NK cell activation in HIV-infected patients [76]. The virus infects macrophages, which provide a reservoir of infection [227]. 5-HT decreases the expression of the HIV coreceptor CCR5 on infected macrophages and reduces proviral synthesis $50 \%[228,229]$. These effects can also be achieved with an agonist targeting $5-\mathrm{HT}_{1}$ but not with one of 5$\mathrm{HT}_{2}$ [229]. Furthermore, SHIV-infected PBMCs from Rhesus monkeys (Macaca mulatta) have 10 times less SERT mRNA than uninfected controls [230]. The authors of this study suggest that low SERT expression may be responsible for the symptoms of depression found in HIV-patients. SSRI drugs are cytotoxic to NK cells taken from HIV-infected patients [76]. Similarly, SSRIs stimulate macrophage activity in vivo and reduce HIV replication in macrophages and $\mathrm{T}$ cells [57]. Interestingly, these effects were independent of patients' psychological status indicating that mood changes are not necessary for 5-HT to have an immunomodulatory effect. These findings suggest that components of the serotonergic system may be suitable therapeutic targets for the control of HIV infection.

Patients infected with hepatitis C virus (HCV) and treated with IFN- $\gamma$ have reduced levels of tryptophan and kynurenine [231], suggesting that 5-HT synthesis and systemic concentrations may be reduced. Furthermore, HCV-infected patients given SSRI therapy have lower viral replication rates [232]. Therefore, SSRIs and/or 5-HTR-targeting drugs may be beneficial for many viral infections.

There is also evidence that SSRIs have antibacterial (especially against gram-negative bacteria) $[233,234]$, antifungal [235], and antiparasitic [79, 236] effects. The available reports establish a direct cytotoxic effect of SSRIs on the pathogen (Box 2). However, it will be interesting to characterize whether immune cells contribute to infection control during SSRI treatment.

Box 2 (selective serotonin reuptake inhibitors (SSRIs) have antiparasitic and antifungal activity). Sertraline and fluoxetina decrease in vitro cell viability of Aspergillus spp. and Candida parapsilosis $[235,237,238]$. Sertraline is likely effective at controlling Leishmania donovani infection in a mouse model by inhibition of parasite respiration [79]. Mianserine decreases the motility of Schistosoma mansoni, the most common species of schitosomes, and 5-HT receptors are expressed in these helminthes at the larvae and adult stages but are overexpressed once they enter NCS [236]. Together 
these results demonstrate that parasites and fungi express SERT-like proteins indicating that they are likely sensitive to SSRIs and systemic changes of 5-HT in the host. Furthermore, the serotonergic system in parasites and fungi may constitute a pharmacological target for drug design. A BLAST search using the human sequence of SERT (gen SLC6A4) against the Aspergillus taxa (taxid: 5052) in the GeneBank database identified seven conserved hypothetical proteins assigned either as uncharacterized eukaryotic solute carrier 6 (EAU35443.1; XP_682235.1; CBF84552.1; XP_001215815.1; EIT73756.1) or sodium/chloride dependent neurotransmitter transporter (XP_001826855.1; XP_002385196.1).

5.1.4. Alzheimer's Disease. Alzheimer's disease is a neurodegenerative disorder and the primary cause of dementia in elderly people [239]. $\beta$-amyloid deposits in senile plaques and neuro-fibrillary tangles that affect brain cell function are characteristic of the disease [240]. Symptoms of dementia and depression, which are related to reduced levels of 5-HT, are present in $50-90 \%$ of patients [241]. NK cells isolated from patients with Alzheimer's disease have a high density of $5-\mathrm{HT}_{2 \mathrm{C}}$ compared with cells from late onset depression patients. However, there is no difference in the level of $5-\mathrm{HT}_{1 \mathrm{~A}}, 5-\mathrm{HT}_{2 \mathrm{~A}}$, and $5-\mathrm{HT}_{2 \mathrm{~B}}$ receptors on PBMCs [72]. The abundant increase of $5-\mathrm{HT}_{2 \mathrm{C}}$ on $\mathrm{NK}$ cells may be a compensatory mechanism for reduced 5-HT availability. Activation of 5- $\mathrm{HT}_{2 \mathrm{C}}$ inhibits $\mathrm{NK}$ cell activity, which may partially explain why Alzheimer's disease patients are more susceptible to viral infections [72, 242].

SSRIs have been used to treat depression in Alzheimer's disease patients. In these patients, SSRIs stimulate cell survival mechanisms, cell adhesion, and lymphocyte activation [243]. Similarly, in a murine model of the disease (hAPP/PS1), chronic oral administration of a $5-\mathrm{HT}_{4}$-selective agonist (SSP-002392) reduced $\beta$-amyloid production and deposition and improved mouse memory [244]. Given the complexity of the cell population expressing $5-\mathrm{HT}_{4}$ in the brain, it is difficult to speculate about a mechanism of action. However, microglial cells may be involved because they express 5$\mathrm{HT}_{4}$ and can phagocytose $\beta$-amyloid deposits, an activity promoted by agonist [244]. This indicates that $5-\mathrm{HT}_{4}$ agonists induce immunomodulation in microglial cells. It remains to be determined whether similarly activated immune cells influence Alzheimer's disease progression and symptoms.

5.2. Diseases with High Systemic Levels of 5-HT. From an immunological point of view, the diseases in this group, such as asthma, arthritis, and cancer, are the result of dysregulated inflammatory responses. Therefore, the association of these diseases with high circulating levels of 5-HT reinforces its role as an immunomodulator.

5.2.1. Asthma. Asthma is a chronic inflammatory disease of the lungs with consequent narrowing of the airways. 5-HT levels are increased in asthma patients and SSRI treatment improves clinical symptoms. In vitro, addition of 5-HT or 5$\mathrm{HT}_{1} / 5-\mathrm{HT}_{2}$ agonists to alveolar macrophages increases the production of IL-10, nitric oxide, and PGE-2, but reduces
TNF- $\alpha$ and IL-12 production. Interestingly, receptor antagonists do not affect secreted-cytokine profiles [177]. Regardless, these results indicate that cytokine production is under the control of 5-HT, and therefore, regulating its systemic concentrations may be useful for asthma patients.

5.2.2. Rheumatoid Arthritis (RA). Rheumatoid arthritis is a chronic disease that causes pain, stiffness, and swelling that limits the motion and function of many joints. While RA can affect any joint, smaller joints of the hands and feet are most commonly involved. Inflammation can affect organs, such as eyes and lungs, in addition to joints. The 5-HT concentrations in platelet-free blood are 1.6- to 2.3-fold higher in RA patients than in healthy controls (reported average serum concentrations were $1130 \mathrm{nmol} / \mathrm{L}$ versus $704 \mathrm{nmol} / \mathrm{L}$, resp.) [245]. This has led to proposals that 5-HT is involved in the pathology, onset, and/or progression of the disease. Treating patients with $5-\mathrm{HT}_{3}$ antagonists combined with intra-articular glucocorticoids has analgesic effects [246]. While there have yet to be any reports on the responses of RA patient immune cells to 5-HT, the role of serotonergic system in arthritis or osteoarthritis has been studied in vitro and in vivo. An osteoarthritis model using cultured synovial tissue demonstrated that 5-HT stimulation increases the expression of $5-\mathrm{HT}_{2 \mathrm{~A}}$ and $5-\mathrm{HT}_{3}$ as well as the release of PGE-2 into the medium. The addition of receptor antagonists inhibits PGE-2 production [74], which may explain the beneficial effects seen in arthritis patients given this treatment [74].

SSRIs can also affect arthritis development. Fluoxetine and citalopram inhibit disease progression in a collageninduced mouse model of arthritis as well as in human RA synovial membranes cultures. In addition, macrophages from RA patients display impaired TLR-3, $-7,-8$, and -9 signaling after SSRI exposure [247]. Therefore the evaluation of SSRIs in RA patients is of interest.

5.2.3. Cancer. While the role of serotonergic system in cancer patients has not been largely studied, advanced stages of breast cancer correlate with increased levels of systemic 5HT [248]. In mouse models of melanoma and lymphoma, SSRI treatment reduced tumor growth by $50 \%$, inhibited IL10 and IFN- $\gamma$ production, and increased IL- $1 \beta$ production [249]. Similarly, exposing a Burkitt's lymphoma cell line to different SSRIs (fluoxetine, paroxetine, or citalopram) decreased DNA synthesis and induced cell death [250]. Although further studies are required, these results suggest that the serotonergic system can impact cancer cells directly or indirectly through immune cell activation.

\section{Conclusions}

Given the importance of 5-HT as a neurotransmitter, studies of the serotonergic system have primarily been limited to the CNS. Recently, however, a large amount of experimental evidence indicates that the serotonergic system has important physiological roles in the immune, vascular, and digestive systems. In this review we discussed the immunomodulatory effects that 5-HT can induce by activating 5HTR and SERT, 
which are differentially expressed on many leukocytes. These effects can be variable depending on cellular phenotype. For example, 5-HT induces dose-dependent cytoskeletal reorganization and diapedesis during chemotaxis as well as granule secretion in granulocytes and myeloid cells. In comparison to these non-transcriptional responses, 5-HT regulates cell proliferation and cytokine production at the transcriptional level in leukocytes.

The human serotonergic system is complex and comprised of many elements. It includes 18 genes, including 5HTRs and one SERT, several of which have multiple isoforms (creating at least 10 additional proteins). Furthermore, the receptor signaling-transduction system that regulates 5HT responses involves a large number of genes [251, 252] providing several points of regulation depending on cellular phenotype. In conclusion, cells of the immune system express transduction machinery that does not necessarily overlap with that in the CNS. This allows for differential responses to the same 5-HT ligand within the immune and nervous systems.

The information presented here is based on existing reports, but we must consider that many early studies of 5-HT receptors used primarily pharmacologic approaches and the results are sometimes not supported by more recent genetic approaches. For example, although early studies suggest role of SERT in T cells, genetic studies suggest that $\mathrm{T}$ cells express DAT (dopamine but also low affinity 5-HT transporter) [253, 254]. Although the effects of 5-HT on the immune system requires further characterization, it is logical to anticipate altered immune responses in patients with dysregulated serotonergic systems. For these patients, experimental evidence suggests that SSRI or 5HTR antagonist treatment may provide beneficial immunomodulatory effects.

\section{Conflict of Interests}

The authors declare no conflict of interests associated with the present paper.

\section{Authors' Contribution}

Rodrigo Arreola; Enrique Becerril-Villanueva; María Eugenia Garcés-Alvarez; Carlos Cruz-Fuentes; Marco Antonio Velasco-Velázquez; Gabriela Hurtado-Alvarado; Saray Quintero-Fabian; and Lenin Pavón drafted the paper. All authors reviewed the paper and approved the final version.

\section{Acknowledgments}

This work was supported in part by the Instituto Nacional de Psiquiatria "Ramón de la Fuente" Project NC150048; CONACYT-INFR-2014-01-225313; CONACYT-CB-2013-01221103, SECITI 0048/2014; Proyecto Factor de TransferenciaIPN: IC-10-002; and PROMEP 14411150. The authors appreciate the assistance of Erick Hernandez Ferreira, MSc. and the support provided by Raul Cardoso (cardoso@imp.edu.mx) and José Luis Calderón, Biomedical Illustration Department of INPRF.

\section{References}

[1] J. Steiner, M. Walter, T. Gos et al., "Severe depression is associated with increased microglial quinolinic acid in subregions of the anterior cingulate gyrus: evidence for an immunemodulated glutamatergic neurotransmission?" Journal of Neuroinflammation, vol. 8, article 94, 2011.

[2] M. Idzko, E. Panther, C. Stratz et al., "The serotoninergic receptors of human dendritic cells: identification and coupling to cytokine release," Journal of Immunology, vol. 172, no. 10, pp. 6011-6019, 2004.

[3] A. Sikander, S. V. Rana, and K. K. Prasad, "Role of serotonin in gastrointestinal motility and irritable bowel syndrome," Clinica Chimica Acta, vol. 403, no. 1-2, pp. 47-55, 2009.

[4] D. L. Murphy, A. M. Andrews, C. H. Wichems, Q. Li, M. Tohda, and B. Greenberg, "Brain serotonin neurotransmission: an overview and update with an emphasis on serotonin subsystem heterogeneity, multiple receptors, interactions with other neurotransmitter systems, and consequent implications for understanding the actions of serotonergic drugs," Journal of Clinical Psychiatry, vol. 59, no. 15, pp. 4-12, 1998.

[5] T. Pronina, M. V. Ugrumov, E. Adamskaya et al., "Influence of serotonin on the development and migration of gonadotropinreleasing hormone neurones in rat foetuses," Journal of Neuroendocrinology, vol. 15, no. 6, pp. 549-558, 2003.

[6] M. Kinoshita, K. Ono, T. Horie et al., "Regulation of adipocyte differentiation by activation of serotonin (5-HT) receptors 5$\mathrm{HT}_{2 A} \mathrm{R}$ and $5-\mathrm{HT}_{2 C} \mathrm{R}$ and involvement of microRNA-448mediated repression of KLF5," Molecular Endocrinology, vol. 24, no. 10, pp. 1978-1987, 2010.

[7] M. Königshoff, R. Dumitrascu, S. Udalov et al., "Increased expression of 5-hydroxytryptamine $2 \mathrm{~A} / \mathrm{B}$ receptors in idiopathic pulmonary fibrosis: a rationale for therapeutic intervention," Thorax, vol. 65, no. 11, pp. 949-955, 2010.

[8] M. D. Gershon, A. B. Drakontides, and L. L. Ross, "Serotonin: synthesis and release from the myenteric plexus of the mouse intestine," Science, vol. 149, no. 3680, pp. 197-199, 1965.

[9] M. D. Gershon and J. Tack, “The serotonin signaling system: from basic understanding to drug development for functional GI disorders," Gastroenterology, vol. 132, no. 1, pp. 397-414, 2007.

[10] I. Cloëz-Tayarani, A.-F. Petit-Bertron, H. D. Venters, and J.-M. Cavaillon, "Differential effect of serotonin on cytokine production in lipopolysaccharide-stimulated human peripheral blood mononuclear cells: involvement of 5-hydroxytryptamine2A receptors," International Immunology, vol. 15, no. 2, pp. 233-240, 2003.

[11] R. Mössner and K.-P. Lesch, "Role of serotonin in the immune system and in neuroimmune interactions," Brain, Behavior, and Immunity, vol. 12, no. 4, pp. 249-271, 1998.

[12] T. C. Janeway, H. B. Richardson, and E. A. Park, "Experiments on the vasoconstrictor action of blood serum," Archives of Internal Medicine, vol. 21, no. 5, pp. 565-603, 1918.

[13] M. Vialli and V. Erspamer, "Ricerche sul secreto delle cellule enterocromaffini. IX Intorno alla natura chimica della sostanza specifica," Bollettino della Societa Medico-Chirurgica di Pavia, vol. 51, pp. 1111-1116, 1937.

[14] M. M. Rapport, A. A. Green, and I. H. Page, "Partial purification of the vasoconstrictor in beef serum," The Journal of Biological Chemistry, vol. 174, no. 2, pp. 735-741, 1948.

[15] M. M. Rapport, A. A. Green, and I. H. Page, "Serum vasoconstrictor, serotonin; isolation and characterization," The Journal of Biological Chemistry, vol. 176, no. 3, pp. 1243-1251, 1948. 
[16] M. M. Rapport, A. A. Green, and I. H. Page, "Crystalline serotonin," Science, vol. 108, no. 2804, pp. 329-330, 1948.

[17] M. M. Rapport, "Serum vasoconstrictor (serotonin) the presence of creatinine in the complex; a proposed structure of the vasoconstrictor principle," The Journal of Biological Chemistry, vol. 180, no. 3, pp. 961-969, 1949.

[18] K. E. Hamlin and F. E. Fischer, "The synthesis of 5hydroxytryptamine," Journal of The American Chemical Society, vol. 73, no. 10, pp. 5007-5008, 1951.

[19] G. Reid and M. Rand, "Pharmacological actions of synthetic 5-hydroxytryptamine (serotonin, thrombocytin)," Nature, vol. 169, no. 4306, pp. 801-802, 1952.

[20] V. Erspamer and B. Asero, "Identification of enteramine, the specific hormone of the enterochromaffin cell system, as 5hydroxytryptamine," Nature, vol. 169, no. 4306, pp. 800-801, 1952.

[21] B. M. Twarog and I. H. Page, "Serotonin content of some mammalian tissues and urine and a method for its determination," The American Journal of Physiology, vol. 175, no. 1, pp. 157-161, 1953.

[22] W. G. Dewhurst, "Amines and abnormal mood," Proceedings of the Royal Society of Medicine, vol. 62, no. 11, pp. 1102-1107, 1969.

[23] T. Canli and K.-P. Lesch, "Long story short: the serotonin transporter in emotion regulation and social cognition," Nature Neuroscience, vol. 10, no. 9, pp. 1103-1109, 2007.

[24] L. Passamonti, M. J. Crockett, A. M. Apergis-Schoute et al., "Effects of acute tryptophan depletion on prefrontal-amygdala connectivity while viewing facial signals of aggression," Biological Psychiatry, vol. 71, no. 1, pp. 36-43, 2012.

[25] J. M. Monti, "Serotonin control of sleep-wake behavior," Sleep Medicine Reviews, vol. 15, no. 4, pp. 269-281, 2011.

[26] J. E. Blundell, "Serotonin and appetite," Neuropharmacology, vol. 23, no. 12, pp. 1537-1551, 1984.

[27] L. Bardin, "The complex role of serotonin and 5-HT receptors in chronic pain," Behavioural Pharmacology, vol. 22, no. 5-6, pp. 390-404, 2011.

[28] P. Ducy, "5-HT and bone biology," Current Opinion in Pharmacology, vol. 11, no. 1, pp. 34-38, 2011.

[29] G. Karsenty and V. K. Yadav, "Regulation of bone mass by serotonin: molecular biology and therapeutic implications," Annual Review of Medicine, vol. 62, pp. 323-331, 2011.

[30] N. Li, N. H. Wallén, M. Ladjevardi, and P. Hjemdahl, "Effects of serotonin on platelet activation in whole blood," Blood Coagulation and Fibrinolysis, vol. 8, no. 8, pp. 517-523, 1997.

[31] M. Lesurtel, C. Soll, R. Graf, and P.-A. Clavien, "Role of serotonin in the hepato-gastroIntestinal tract: an old molecule for new perspectives," Cellular and Molecular Life Sciences, vol. 65, no. 6, pp. 940-952, 2008.

[32] M. R. Irwin and A. H. Miller, "Depressive disorders and immunity: 20 years of progress and discovery," Brain, Behavior, and Immunity, vol. 21, no. 4, pp. 374-383, 2007.

[33] M. Masana, N. Santana, F. Artigas, and A. Bortolozzi, "Dopamine neurotransmission and atypical antipsychotics in prefrontal cortex: a critical review," Current Topics in Medicinal Chemistry, vol. 12, no. 21, pp. 2357-2374, 2012.

[34] S. Tanahashi, S. Yamamura, M. Nakagawa, E. Motomura, and M. Okada, "Dopamine D2 and serotonin 5-HT1A receptors mediate the actions of aripiprazole in mesocortical and mesoaccumbens transmission," Neuropharmacology, vol. 62, no. 2, pp. 765-774, 2012.
[35] M. Abdouh, J. M. Storring, M. Riad et al., "Transcriptional mechanisms for induction of $5-\mathrm{HT}_{1 A}$ receptor mRNA and protein in activated B and T lymphocytes," The Journal of Biological Chemistry, vol. 276, no. 6, pp. 4382-4388, 2001.

[36] M. Abdouh, P. R. Albert, E. Drobetsky, J. G. Filep, and E. Kouassi, "5-HT1A-mediated promotion of mitogen-activated T and B cell survival and proliferation is associated with increased translocation of NF-kappaB to the nucleus," Brain, Behavior, and Immunity, vol. 18, no. 1, pp. 24-34, 2004.

[37] T. M. Aune, H. W. Golden, and K. M. McGrath, "Inhibitors of serotonin synthesis and antagonists of serotonin $1 \mathrm{~A}$ receptors inhibit $\mathrm{T}$ lymphocyte function in vitro and cell-mediated immunity in vivo," Journal of Immunology, vol. 153, no. 2, pp. 489-498, 1994.

[38] N. M. Kushnir-Sukhov, A. M. Gilfillan, J. W. Coleman et al., "5hydroxytryptamine induces mast cell adhesion and migration," The Journal of Immunology, vol. 177, no. 9, pp. 6422-6432, 2006.

[39] B. N. Kang, S. G. Ha, N. S. Bahaie et al., "Regulation of serotonin-induced trafficking and migration of eosinophils," PLoS ONE, vol. 8, no. 1, Article ID e54840, 2013.

[40] M. León-Ponte, G. P. Ahern, and P. J. O’Connell, “Serotonin provides an accessory signal to enhance T-cell activation by signaling through the 5-HT7 receptor," Blood, vol. 109, no. 8, pp. 3139-3146, 2007.

[41] K. Iken, S. Chheng, A. Fargin, A.-C. Goulet, and E. Kouassi, "Serotonin upregulates mitogen-stimulated B lymphocyte proliferation through 5-HT1A receptors," Cellular Immunology, vol. 163, no. 1, pp. 1-9, 1995.

[42] T. Dürk, E. Panther, T. Müller et al., "5-hydroxytryptamine modulates cytokine and chemokine production in LPS-primed human monocytes via stimulation of different 5-HTR subtypes," International Immunology, vol. 17, no. 5, pp. 599-606, 2005.

[43] T. Müller, T. Dürk, B. Blumenthal et al., "5-hydroxytryptamine modulates migration, cytokine and chemokine release and Tcell priming capacity of dendritic cells in vitro and in vivo," PLoS ONE, vol. 4, no. 7, Article ID e6453, 2009.

[44] T. Rivera-Baltanas, J. M. Olivares, J. R. Martinez-Villamarin, E. Y. Fenton, L. E. Kalynchuk, and H. J. Caruncho, "Serotonin 2A receptor clustering in peripheral lymphocytes is altered in major depression and may be a biomarker of therapeutic efficacy," Journal of Affective Disorders, vol. 163, pp. 47-55, 2014.

[45] S. A. Boehme, F. M. Lio, L. Sikora et al., "Cutting edge: Serotonin is a chemotactic factor for eosinophils and functions additively with eotaxin," Journal of Immunology, vol. 173, no. 6, pp. 35993603, 2004.

[46] E. Magrini, I. Szabò, A. Doni, J. Cibella, and A. Viola, "Serotonin-mediated tuning of human helper $\mathrm{T}$ cell responsiveness to the chemokine CXCL12," PLoS ONE, vol. 6, no. 8, Article ID e22482, 2011.

[47] B. L. Fiebich, R. S. Akundi, M. Seidel et al., "Expression of 5HT3A receptors in cells of the immune system," Scandinavian Journal of Rheumatology, vol. 33, supplement 119, pp. 9-11, 2004.

[48] A. Rinaldi, A. M. Chiaravalli, M. Mian et al., "Serotonin receptor 3A expression in normal and neoplastic B cells," Pathobiology, vol. 77, no. 3, pp. 129-135, 2010.

[49] J. D. Holbrook, C. H. Gill, N. Zebda et al., "Characterisation of $5-\mathrm{HT}_{3 C}, 5-\mathrm{HT}_{3 D}$ and $5-\mathrm{HT}_{3 E}$ receptor subunits: evolution, distribution and function," Journal of Neurochemistry, vol. 108, no. 2, pp. 384-396, 2009.

[50] N. Katoh, F. Soga, T. Nara et al., "Effect of serotonin on the differentiation of human monocytes into dendritic cells," 
Clinical and Experimental Immunology, vol. 146, no. 2, pp. 354361, 2006.

[51] B. A. Faraj, Z. L. Olkowski, and R. T. Jackson, "Expression of a high-affinity serotonin transporter in human lymphocytes," International Journal of Immunopharmacology, vol. 16, no. 7, pp. 561-567, 1994.

[52] L. Lima and M. Urbina, "Serotonin transporter modulation in blood lymphocytes from patients with major depression," Cellular and Molecular Neurobiology, vol. 22, no. 5-6, pp. 797804, 2002.

[53] F. Fazzino, M. Urbina, N. Cedeño, and L. Lima, "Fluoxetine treatment to rats modifies serotonin transporter and cAMP in lymphocytes, $\mathrm{CD} 4^{+}$and $\mathrm{CD} 8^{+}$subpopulations and interleukins 2 and 4," International Immunopharmacology, vol. 9, no. 4, pp. 463-467, 2009.

[54] T. Rivera-Baltanas, J. M. Olivares, M. Calado-Otero, L. E. Kalynchuk, J. R. Martinez-Villamarin, and H. J. Caruncho, "Serotonin transporter clustering in blood lymphocytes as a putative biomarker of therapeutic efficacy in major depressive disorder," Journal of Affective Disorders, vol. 137, no. 1-3, pp. 4655, 2012.

[55] M. Medina-Martel, M. Urbina, F. Fazzino, and L. Lima, "Serotonin transporter in lymphocytes of rats exposed to physical restraint stress," NeuroImmunoModulation, vol. 20, no. 6, pp. 361-367, 2013.

[56] J.-I. Iga, S.-I. Ueno, K. Yamauchi et al., "Serotonin transporter mRNA expression in peripheral leukocytes of patients with major depression before and after treatment with paroxetine," Neuroscience Letters, vol. 389, no. 1, pp. 12-16, 2005.

[57] T. Benton, K. Lynch, B. Dubé et al., "Selective serotonin reuptake inhibitor suppression of HIV infectivity and replication," Psychosomatic Medicine, vol. 72, no. 9, pp. 925-932, 2010.

[58] P. J. O'Connell, X. Wang, M. Leon-Ponte, C. Griffiths, S. C. Pingle, and G. P. Ahern, "A novel form of immune signaling revealed by transmission of the inflammatory mediator serotonin between dendritic cells and T cells," Blood, vol. 107, no. 3, pp. 1010-1017, 2006.

[59] K. Thorslund, B. Amatya, A. E. Dufva, and K. Nordlind, "The expression of serotonin transporter protein correlates with the severity of psoriasis and chronic stress," Archives of Dermatological Research, vol. 305, no. 2, pp. 99-104, 2013.

[60] M. H. Andersen, "The specific targeting of immune regulation: T-cell responses against Indoleamine 2,3-dioxygenase," Cancer Immunology, Immunotherapy, vol. 61, no. 8, pp. 1289-1297, 2012.

[61] G. Furset, Y. Fløisand, and M. Sioud, "Impaired expression of indoleamine 2, 3-dioxygenase in monocyte-derived dendritic cells in response to Toll-like receptor-7/8 ligands," Immunology, vol. 123, no. 2, pp. 263-271, 2008.

[62] P. Chaitidis, E. E. Billett, V. B. O’Donnell et al., "Th2 response of human peripheral monocytes involves isoform-specific induction of monoamine oxidase-A," Journal of Immunology, vol. 173, no. 8, pp. 4821-4827, 2004.

[63] R. Mössner, O. Mikova, E. Koutsilieri et al., "Consensus paper of the WFSBP task force on biological markers: biological markers in depression," World Journal of Biological Psychiatry, vol. 8, no. 3, pp. 141-174, 2007.

[64] F. Fazzino, C. Montes, M. Urbina, I. Carreira, and L. Lima, "Serotonin transporter is differentially localized in subpopulations of lymphocytes of major depression patients. Effect of fluoxetine on proliferation," Journal of Neuroimmunology, vol. 196, no. 1-2, pp. 173-180, 2008.
[65] S. Peña, E. Baccichet, M. Urbina, I. Carreira, and L. Lima, "Effect of mirtazapine treatment on serotonin transporter in blood peripheral lymphocytes of major depression patients," International Immunopharmacology, vol. 5, no. 6, pp. 1069-1076, 2005.

[66] L. Bazzichi, G. Giannaccini, L. Betti et al., "Alteration of serotonin transporter density and activity in fibromyalgia," Arthritis Research \& Therapy, vol. 8, article R99, 2006.

[67] J. Williams, P. McGuffin, M. Nothen, and M. J. Owen, "Meta-analysis of association between the 5-HT2a receptor T102C polymorphism and schizophrenia. EMASS Collaborative Group. European Multicentre Association Study of Schizophrenia," The Lancet, vol. 349, no. 9060, article 1221, 1997.

[68] H. M. Abdolmaleky, S. V. Faraone, S. J. Glatt, and M. T. Tsuang, "Meta-analysis of association between the T102C polymorphism of the 5HT2a receptor gene and schizophrenia," Schizophrenia Research, vol. 67, no. 1, pp. 53-62, 2004.

[69] G. R. Shariati, G. Ahangari, A. Hossein-nezhad, S. M. Asadi, F. Pooyafard, and H. R. Ahmadkhaniha, "Expression changes of serotonin receptor gene subtype 5HT3a in peripheral blood mononuclear cells from schizophrenic patients treated with haloperidol and olanzapin," Iranian Journal of Allergy, Asthma and Immunology, vol. 8, no. 3, pp. 135-139, 2009.

[70] D. Marazziti, B. Dell'Osso, S. Baroni et al., "Common alterations in the serotonin transporter in platelets and lymphocytes of psychotic patients," Pharmacopsychiatry, vol. 39, no. 1, pp. 3538, 2006.

[71] F. Lechin, B. van der Dijs, B. Orozco et al., "The serotonin uptake-enhancing drug tianeptine suppresses asthmatic symptoms in children: a double-blind, crossover, placebo-controlled study," Journal of Clinical Pharmacology, vol. 38, no. 10, pp. 918925, 1998.

[72] L. C. A. Martins, N. P. Rocha, K. C. L. Torres et al., "Diseasespecific expression of the serotonin-receptor $5-\mathrm{HT}_{2 \mathrm{C}}$ in natural killer cells in Alzheimer's dementia," Journal of Neuroimmunology, vol. 251, no. 1-2, pp. 73-79, 2012.

[73] D. K. Babu, A. Diaz, T. Samikkannu et al., "Upregulation of serotonin transporter by alcohol in human dendritic cells: possible implication in neuroimmune deregulation," Alcoholism: Clinical and Experimental Research, vol. 33, no. 10, pp. 1731-1738, 2009.

[74] M. F. Seidel, B. L. Fiebich, G. Ulrich-Merzenich, E. CandelarioJalil, F.-W. Koch, and H. Vetter, "Serotonin mediates PGE2 overexpression through 5-HT2A and 5-HT3 receptor subtypes in serum-free tissue culture of macrophage-like synovial cells," Rheumatology International, vol. 28, no. 10, pp. 1017-1022, 2008.

[75] M. Urbina, R. Arroyo, and L. Lima, "5-HT 7 receptors and tryptophan hydroxylase in lymphocytes of rats: mitogen activation, physical restraint or treatment with reserpine," Neuroimmunomodulation, vol. 21, no. 5, pp. 240-249, 2014.

[76] D. L. Evans, K. G. Lynch, T. Benton et al., "Selective serotonin reuptake inhibitor and substance $\mathrm{P}$ antagonist enhancement of natural killer cell innate immunity in human immunodeficiency virus/acquired immunodeficiency syndrome," Biological Psychiatry, vol. 63, no. 9, pp. 899-905, 2008.

[77] M. Schaefer, R. Sarkar, V. Knop et al., "Escitalopram for the prevention of peginterferon- $\alpha 2 \mathrm{a}$-associated depression in hepatitis $C$ virus-infected patients without previous psychiatric disease: a randomized trial," Annals of Internal Medicine, vol. 157, no. 2, pp. 94-103, 2012.

[78] W. Müller and T. Stratz, "Local treatment of tendinopathies and myofascial pain syndromes with the $5-\mathrm{HT}_{3}$ receptor antagonist 
tropisetron," Scandinavian Journal of Rheumatology, vol. 33, no. s119, pp. 44-48, 2004.

[79] P. Palit and N. Ali, "Oral therapy with sertraline, a selective serotonin reuptake inhibitor, shows activity against Leishmania donovani," Journal of Antimicrobial Chemotherapy, vol. 61, no. 5, pp. 1120-1124, 2008.

[80] C.-K. Fang, H.-W. Chen, I.-T. Chiang et al., "Mirtazapine inhibits tumor growth via immune response and serotonergic system," PLoS ONE, vol. 7, no. 7, Article ID e38886, 2012.

[81] D. E. Nichols and C. D. Nichols, "Serotonin receptors," Chemical Reviews, vol. 108, no. 5, pp. 1614-1641, 2008.

[82] R. Schwarcz, J. P. Bruno, P. J. Muchowski, and H.-Q. Wu, "Kynurenines in the mammalian brain: when physiology meets pathology," Nature Reviews Neuroscience, vol. 13, no. 7, pp. 465477, 2012.

[83] S. O. Silva, M. R. Rodrigues, S. R. Q. Carvalho, L. H. Catalani, A. Campa, and V. F. Ximenes, "Oxidation of melatonin and its catabolites, N1-acetyl-N 2-formyl-5-methoxykynuramine and N1-acetyl-5- methoxykynuramine, by activated leukocytes," Journal of Pineal Research, vol. 37, no. 3, pp. 171-175, 2004.

[84] T. W. Stone and L. G. Darlington, "Endogenous kynurenines as targets for drug discovery and development," Nature Reviews Drug Discovery, vol. 1, no. 8, pp. 609-620, 2002.

[85] L. Vécsei, L. Szalárdy, F. Fülöp, and J. Toldi, "Kynurenines in the CNS: recent advances and new questions," Nature Reviews Drug Discovery, vol. 12, no. 1, pp. 64-82, 2013.

[86] A. Carrillo-Vico, P. J. Lardone, N. Álvarez-Śnchez, A. Rodrĩguez-Rodrĩguez, and J. M. Guerrero, "Melatonin: buffering the immune system," International Journal of Molecular Sciences, vol. 14, no. 4, pp. 8638-8683, 2013.

[87] D. J. Walther and M. Bader, "A unique central tryptophan hydroxylase isoform," Biochemical Pharmacology, vol. 66, no. 9, pp. 1673-1680, 2003.

[88] D. J. Walther, J.-U. Peter, S. Bashammakh et al., "Synthesis of serotonin by a second tryptophan hydroxylase isoform," Science, vol. 299, no. 5603, p. 76, 2003.

[89] S. A. Sakowski, T. J. Geddes, D. M. Thomas, E. Levi, J. S. Hatfield, and D. M. Kuhn, "Differential tissue distribution of tryptophan hydroxylase isoforms 1 and 2 as revealed with monospecific antibodies," Brain Research, vol. 1085, no. 1, pp. 11-18, 2006.

[90] D.-Y. Kim and M. Camilleri, "Serotonin: a mediator of the brain-gut connection," The American Journal of Gastroenterology, vol. 95, no. 10, pp. 2698-2709, 2000.

[91] M. C. Boadle-Biber, "Regulation of serotonin synthesis," Progress in Biophysics and Molecular Biology, vol. 60, no. 1, pp. $1-15,1993$.

[92] G. M. Tyce, “Origin and metabolism of serotonin," Journal of Cardiovascular Pharmacology, vol. 16, supplement 3, pp. S1-S7, 1990.

[93] D. Acuña-Castroviejo, G. Escames, C. Venegas et al., "Extrapineal melatonin: sources, regulation, and potential functions," Cellular and Molecular Life Sciences, vol. 71, no. 16, pp. 29973025, 2014.

[94] L. M. E. Finocchiaro, V. E. Nahmod, and J. M. Launay, "Melatonin biosynthesis and metabolism in peripheral blood mononuclear leucocytes," Biochemical Journal, vol. 280, part 3, pp. 727-731, 1991.

[95] J. C. Mayo, R. M. Sainz, D.-X. Tan et al., "Anti-inflammatory actions of melatonin and its metabolites, N1-acetyl-N2formyl-5-methoxykynuramine (AFMK) and N1-acetyl-5methoxykynuramine (AMK), in macrophages," Journal of Neuroimmunology, vol. 165, no. 1-2, pp. 139-149, 2005.
[96] R. M. Slominski, R. J. Reiter, N. Schlabritz-Loutsevitch, R. S. Ostrom, and A. T. Slominski, "Melatonin membrane receptors in peripheral tissues: distribution and functions," Molecular and Cellular Endocrinology, vol. 351, no. 2, pp. 152-166, 2012.

[97] R. Lozda and I. Purviņš, "Quantification of serotonin Osulphate by LC-MS method in plasma of healthy volunteers," Frontiers in Pharmacology, vol. 5, article 62, 2014.

[98] M. Okuma, T. Tokuyama, S. Senoh, F. Hirata, and O. Hayaishi, "Antagonism of 5-hydroxykynurenamine against serotonin action on platelet aggregation," Proceedings of the National Academy of Sciences of the United States of America, vol. 73, no. 2, pp. 643-645, 1976.

[99] M. P. Heyes, K. Saito, and S. P. Markey, "Human macrophages convert L-tryptophan into the neurotoxin quinolinic acid," Biochemical Journal, vol. 283, no. 3, pp. 633-635, 1992.

[100] M. P. Heyes, C. L. Achim, C. A. Wiley, E. O. Major, K. Saito, and S. P. Markey, "Human microglia convert l-tryptophan into the neurotoxin quinolinic acid," Biochemical Journal, vol. 320, part 2, pp. 595-597, 1996.

[101] Y. Mándi and L. Vécsei, "The kynurenine system and immunoregulation," Journal of Neural Transmission, vol. 119, no. 2, pp. 197-209, 2012.

[102] H. Xu, G. X. Zhang, B. Ciric, and A. Rostami, "IDO: a doubleedged sword for TH1/TH2 regulation," Immunology Letters, vol. 121, no. 1, pp. 1-6, 2008.

[103] G. Frumento, R. Rotondo, M. Tonetti, G. Damonte, U. Benatti, and G. B. Ferrara, "Tryptophan-derived catabolites are responsible for inhibition of $\mathrm{T}$ and natural killer cell proliferation induced by indoleamine 2,3-dioxygenase," The Journal of Experimental Medicine, vol. 196, no. 4, pp. 459-468, 2002.

[104] L. N. Squires, J. A. Jakubowski, J. N. Stuart et al., "Serotonin catabolism and the formation and fate of 5-hydroxyindole thiazolidine carboxylic acid," The Journal of Biological Chemistry, vol. 281, no. 19, pp. 13463-13470, 2006.

[105] A. J. Harmar, R. A. Hills, E. M. Rosser et al., "IUPHAR-DB: the IUPHAR database of G protein-coupled receptors and ion channels," Nucleic Acids Research, vol. 37, pp. D680-D685, 2009.

[106] J. L. Sharman, H. E. Benson, A. J. Pawson et al., "IUPHARDB: updated database content and new features," Nucleic Acids Research, vol. 41, no. 1, pp. D1083-D1088, 2013.

[107] C. M. Villalón and D. Centurión, "Cardiovascular responses produced by 5-hydroxytriptamine: a pharmacological update on the receptors/mechanisms involved and therapeutic implications," Naunyn-Schmiedeberg's Archives of Pharmacology, vol. 376, no. 1-2, pp. 45-63, 2007.

[108] L. C. Berumen, A. Rodríguez, R. Miledi, and G. García-Alcocer, "Serotonin receptors in hippocampus," The Scientific World Journal, vol. 2012, Article ID 823493, 15 pages, 2012.

[109] Z. Sun, X. Tang, F. Lin, and S. Chen, "The WD40 repeat protein WDR26 binds G $\beta \gamma$ and promotes $G \beta \gamma$-dependent signal transduction and leukocyte migration," The Journal of Biological Chemistry, vol. 286, no. 51, pp. 43902-43912, 2011.

[110] Y. Lin and A. V. Smrcka, "Understanding molecular recognition by $\mathrm{G}$ protein betagamma subunits on the path to pharmacological targeting," Molecular Pharmacology, vol. 80, no. 4, pp. 551557, 2011.

[111] Z. Xie, S. P. Lee, B. F. O’Dowd, and S. R. George, "Serotonin 5$\mathrm{HT}_{1 B}$ and $5-\mathrm{HT}_{1 D}$ receptors form homodimers when expressed alone and heterodimers when co-expressed," FEBS Letters, vol. 456, no. 1, pp. 63-67, 1999. 
[112] K. Herrick-Davis, E. Grinde, and J. E. Mazurkiewicz, "Biochemical and biophysical characterization of serotonin $5-\mathrm{HT}_{2 \mathrm{C}}$ receptor homodimers on the plasma membrane of living cells," Biochemistry, vol. 43, no. 44, pp. 13963-13971, 2004.

[113] K. Herrick-Davis, B. A. Weaver, E. Grinde, and J. E. Mazurkiewicz, "Serotonin 5-HT2C receptor homodimer biogenesis in the endoplasmic reticulum: Real-time visualization with confocal fluorescence resonance energy transfer," The Journal of Biological Chemistry, vol. 281, no. 37, pp. 27109-27116, 2006.

[114] K. Herrick-Davis, E. Grinde, T. Lindsley, A. Cowan, and J. E. Mazurkiewicz, "Oligomer size of the serotonin 5-hydroxytryptamine 2C (5-HT2C) receptor revealed by fluorescence correlation spectroscopy with photon counting histogram analysis: evidence for homodimers without monomers or tetramers," Journal of Biological Chemistry, vol. 287, no. 28, pp. 2360423614, 2012

[115] K. Herrick-Davis, E. Grinde, T. J. Harrigan, and J. E. Mazurkiewicz, "Inhibition of serotonin 5-hydroxytryptamine $2 \mathrm{C}$ receptor function through heterodimerization: receptor dimers bind two molecules of ligand and one G-protein," The Journal of Biological Chemistry, vol. 280, no. 48, pp. 40144-40151, 2005.

[116] L. P. Pellissier, G. Barthet, F. Gaven et al., "G protein activation by serotonin type 4 receptor dimers. Evidence that turning on two protomers is more efficient," The Journal of Biological Chemistry, vol. 286, no. 12, pp. 9985-9997, 2011.

[117] G. Milligan, "G protein-coupled receptor dimerisation: molecular basis and relevance to function," Biochimica et Biophysica Acta-Biomembranes, vol. 1768, no. 4, pp. 825-835, 2007.

[118] S. Ganguly, A. H. A. Clayton, and A. Chattopadhyay, "Organization of higher-order oligomers of the serotonin1A receptor explored utilizing homo-FRET in live cells," Biophysical Journal, vol. 100, no. 2, pp. 361-368, 2011.

[119] C. Wang, Y. Jiang, J. Ma et al., "Structural basis for molecular recognition at serotonin receptors," Science, vol. 340, no. 6132, pp. 610-614, 2013.

[120] D. Wacker, C. Wang, V. Katritch et al., "Structural features for functional selectivity at serotonin receptors," Science, vol. 340, no. 6132, pp. 615-619, 2013.

[121] N. P. Barrera, P. Herbert, R. M. Henderson, I. L. Martin, and J. M. Edwardson, "Atomic force microscopy reveals the stoichiometry and subunit arrangement of 5-HT3 receptors," Proceedings of the National Academy of Sciences of the United States of America, vol. 102, no. 35, pp. 12595-12600, 2005.

[122] A. A. Jensen, P. A. Davies, H. Bräuner-Osborne, and K. Krzywkowski, "3B but which $3 \mathrm{~B}$ ? And that's just one of the questions: the heterogeneity of human $5-\mathrm{HT}_{3}$ receptors," Trends in Pharmacological Sciences, vol. 29, no. 9, pp. 437-444, 2008.

[123] N. M. Barnes, T. G. Hales, S. C. R. Lummis, and J. A. Peters, "The $5-\mathrm{HT}_{3}$ receptor-the relationship between structure and function," Neuropharmacology, vol. 56, no. 1, pp. 273-284, 2009.

[124] S. M. Sine and A. G. Engel, "Recent advances in Cys-loop receptor structure and function," Nature, vol. 440, no. 7083, pp. 448-455, 2006.

[125] J. A. Peters, T. G. Hales, and J. J. Lambert, "Molecular determinants of single-channel conductance and ion selectivity in the Cys-loop family: insights from the 5-HT3 receptor," Trends in Pharmacological Sciences, vol. 26, no. 11, pp. 587-594, 2005.
[126] H. Sun, X.-Q. Hu, E. M. Moradel, F. F. Weight, and L. Zhang, "Modulation of $5-\mathrm{HT}_{3}$ receptor-mediated response and trafficking by activation of protein kinase C," The Journal of Biological Chemistry, vol. 278, no. 36, pp. 34150-34157, 2003.

[127] N. Yaakob, D. T. Malone, B. Exintaris, and H. R. Irving, "Heterogeneity amongst 5-HT3 receptor subunits: is this significant?" Current Molecular Medicine, vol. 11, no. 1, pp. 57-68, 2011.

[128] A. M. Karnovsky, L. F. Gotow, D. D. McKinley et al., "A cluster of novel serotonin receptor 3-like genes on human chromosome 3," Gene, vol. 319, no. 1-2, pp. 137-148, 2003.

[129] B. Niesler, B. Frank, J. Kapeller, and G. A. Rappold, "Cloning, physical mapping and expression analysis of the human $5-\mathrm{HT}_{3}$ serotonin receptor-like genes HTR3C, HTR3D and HTR3E," Gene, vol. 310, no. 1-2, pp. 101-111, 2003.

[130] D. Belelli, J. M. Balcarek, A. G. Hope, J. A. Peters, J. J. Lambert, and T. P. Blackburn, "Cloning and functional expression of a human 5-hydroxytryptamine type 3AS receptor subunit," Molecular Pharmacology, vol. 48, no. 6, pp. 1054-1062, 1995.

[131] B. Niesler, J. Walstab, S. Combrink et al., "Characterization of the novel human serotonin receptor subunits 5-HT3C,5-HT3D, and 5-HT3E," Molecular Pharmacology, vol. 72, no. 1, pp. 8-17, 2007.

[132] M. Ohara-Imaizumi, H. Kim, M. Yoshida et al., "Serotonin regulates glucose-stimulated insulin secretion from pancreatic $\beta$ cells during pregnancy," Proceedings of the National Academy of Sciences of the United States of America, vol. 110, no. 48, pp. 19420-19425, 2013.

[133] J. A. van Hooft and H. P. M. Vijverberg, "5-HT(3) receptors and neurotransmitter release in the CNS: a nerve ending story?" Trends in Neurosciences, vol. 23, no. 12, pp. 605-610, 2000.

[134] B. L. Fiebich, R. S. Akundi, K. Lieb et al., "Antiinflammatory effects of $5-\mathrm{HT}_{3}$ receptor antagonists in lipopolysaccharidestimulated primary human monocytes," Scandinavian Journal of Rheumatology, Supplement, vol. 33, no. 119, pp. 28-32, 2004.

[135] C. Stratz, H. S. Bhatia, R. S. Akundi et al., "The anti-inflammatory effects of the $5-\mathrm{HT}_{3}$ receptor antagonist tropisetron are mediated by the inhibition of $\mathrm{p} 38$ MAPK activation in primary human monocytes," International Immunopharmacology, vol. 13, no. 4, pp. 398-402, 2012.

[136] C. P. Mercado and F. Kilic, "Molecular mechanisms of sert in platelets: regulation of plasma serotonin levels," Molecular Interventions, vol. 10, no. 4, pp. 231-241, 2010.

[137] M. A. Margoob and D. Mushtaq, "Serotonin transporter gene polymorphism and psychiatric disorders: Is there a link," Indian Journal of Psychiatry, vol. 53, no. 4, pp. 289-299, 2011.

[138] F. Kilic and G. Rudnick, "Oligomerization of serotonin transporter and its functional consequences," Proceedings of the National Academy of Sciences of the United States of America, vol. 97, no. 7, pp. 3106-3111, 2000.

[139] A. M. Kocabas, G. Rudnick, and F. Kilic, "Functional consequences of homo- but not hetero-oligomerization between transporters for the biogenic amine neurotransmitters," Journal of Neurochemistry, vol. 85, no. 6, pp. 1513-1520, 2003.

[140] D. Ozaslan, S. Wang, B. A. Ahmed et al., "Glycosyl modification facilitates homo- and hetero-oligomerization of the serotonin transporter. A specific role for sialic acid residues," The Journal of Biological Chemistry, vol. 278, no. 45, pp. 43991-44000, 2003.

[141] C. P. Mercado, E. Ziu, and F. Kilic, "Communication between 5HT and small GTPases," Current Opinion in Pharmacology, vol. 11, no. 1, pp. 23-28, 2011. 
[142] D. J. Walther, J.-U. Peter, S. Winter et al., "Serotonylation of small GTPases is a signal transduction pathway that triggers platelet alpha-granule release," Cell, vol. 115, no. 7, pp. 851-862, 2003.

[143] N. Paulmann, M. Grohmann, J.-P. Voigt et al., "Intracellular serotonin modulates insulin secretion from pancreatic $\beta$-cells by protein serotonylation," PLoS Biology, vol. 7, no. 10, Article ID e1000229, 2009.

[144] R. Shirakawa, A. Yoshioka, H. Horiuchi, H. Nishioka, A. Tabuchi, and T. Kita, "Small GTPase Rab4 regulates $\mathrm{Ca}^{2+}$ induced alpha-granule secretion in platelets," The Journal of Biological Chemistry, vol. 275, no. 43, pp. 33844-33849, 2000.

[145] S. M. Schoenwaelder, S. C. Hughan, K. Boniface et al., "RhoA sustains integrin alpha IIbbeta 3 adhesion contacts under high shear," The Journal of Biological Chemistry, vol. 277, no. 17, pp. 14738-14746, 2002.

[146] A. Hall and G. Lalli, "Rho and Ras GTPases in axon growth, guidance, and branching," Cold Spring Harbor Perspectives in Biology, vol. 2, no. 2, Article ID a001818, 2010.

[147] O. Visvikis, M. P. Maddugoda, and E. Lemichez, "Direct modifications of Rho proteins: deconstructing GTPase regulation," Biology of the Cell, vol. 102, no. 7, pp. 377-389, 2010.

[148] C. Guilluy, M. Rolli-Derkinderen, P.-L. Tharaux, G. Melino, P. Pacaud, and G. Loirand, "Transglutaminase-dependent RhoA activation and depletion by serotonin in vascular smooth muscle cells," The Journal of Biological Chemistry, vol. 282, no. 5, pp. 2918-2928, 2007.

[149] K. Vikenes, M. Farstad, and J. E. Nordrehaug, "Serotonin is associated with coronary artery disease and cardiac events," Circulation, vol. 100, no. 5, pp. 483-489, 1999.

[150] Y. Liu, L. Wei, D. L. Laskin, and B. L. Fanburg, "Role of protein transamidation in serotonin-induced proliferation and migration of pulmonary artery smooth muscle cells," American Journal of Respiratory Cell and Molecular Biology, vol. 44, no. 4, pp. 548-555, 2011.

[151] M. Ostrowski, N. B. Carmo, S. Krumeich et al., "Rab27a and Rab27b control different steps of the exosome secretion pathway," Nature Cell Biology, vol. 12, no. 1, pp. 19-30, 2010.

[152] E. K. Novak, R. Gautam, M. Reddington et al., "The regulation of platelet-dense granules by Rab27a in the ashen mouse, a model of Hermansky-Pudlak and Griscelli syndromes, is granule-specific and dependent on genetic background," Blood, vol. 100, no. 1, pp. 128-135, 2002.

[153] T. Tolmachova, M. Åbrink, C. E. Futter, K. S. Authi, and M. C. Seabra, "Rab27b regulates number and secretion of platelet dense granules," Proceedings of the National Academy of Sciences of the United States of America, vol. 104, no. 14, pp. 5872-5877, 2007.

[154] Z. Yi, H. Yokota, S. Torii et al., "The Rab27a/granuphilin complex regulates the exocytosis of insulin-containing densecore granules," Molecular and Cellular Biology, vol. 22, no. 6, pp. 1858-1867, 2002.

[155] A. Imai, S. Yoshie, T. Nashida, H. Shimomura, and M. Fukuda, "The small GTPase Rab27B regulates amylase release from rat parotid acinar cells," Journal of Cell Science, vol. 117, no. 10, pp. 1945-1953, 2004.

[156] B. A. Ahmed, I. A. Bukhari, B. C. Jeffus et al., "The cellular distribution of serotonin transporter is impeded on serotoninaltered vimentin network," PLoS ONE, vol. 4, no. 3, Article ID e4730, 2009.

[157] B. A. Ahmed, B. C. Jeffus, S. I. A. Bukhari et al., "Serotonin transamidates Rab4 and facilitates its binding to the $\mathrm{C}$ terminus of serotonin transporter," The Journal of Biological Chemistry, vol. 283, no. 14, pp. 9388-9398, 2008.

[158] E. K. Haddad, X. Wu, J. A. Hammer III, and P. A. Henkart, "Defective granule exocytosis in Rab27a-deficient lymphocytes from Ashen mice," The Journal of Cell Biology, vol. 152, no. 4, pp. 835-842, 2001.

[159] J. C. Stinchcombe and G. M. Griffiths, "Normal and abnormal secretion by haemopoietic cells," Immunology, vol. 103, no. 1, pp. 10-16, 2001.

[160] M. Angel, del Pozo, M. Vicente-Manzanares, R. Tejedor, J. M. Serrador, and F. Sánchez-Madrid, "Rho GTPases control migration and polarization of adhesion molecules and cytoskeletal ERM components in T lymphocytes," European Journal of Immunology, vol. 29, no. 11, pp. 3609-3620, 1999.

[161] A. Bellizzi, A. Mangia, A. Chiriatti et al., "RhoA protein expression in primary breast cancers and matched lymphocytes is associated with progression of the disease," International Journal of Molecular Medicine, vol. 22, no. 1, pp. 25-31, 2008.

[162] M. J. Brown, J. A. Hallam, E. Colucci-Guyon, and S. Shaw, "Rigidity of circulating lymphocytes is primarily conferred by vimentin intermediate filaments," The Journal of Immunology, vol. 166, no. 11, pp. 6640-6646, 2001.

[163] G. P. Ahern, "5-HT and the immune system," Current Opinion in Pharmacology, vol. 11, no. 1, pp. 29-33, 2011.

[164] B. S. Beikmann, I. D. Tomlinson, S. J. Rosenthal, and A. M. Andrews, "Serotonin uptake is largely mediated by platelets versus lymphocytes in peripheral blood cells," ACS Chemical Neuroscience, vol. 4, no. 1, pp. 161-170, 2013.

[165] S. W. Watts, J. R. C. Priestley, and J. M. Thompson, "Serotonylation of vascular proteins important to contraction," PLOS ONE, vol. 4, no. 5, Article ID e5682, 2009.

[166] F. Hayashi, T. K. Means, and A. D. Luster, "Toll-like receptors stimulate human neutrophil function," Blood, vol. 102, no. 7, pp. 2660-2669, 2003.

[167] D. Duerschmied, G. L. Suidan, M. Demers et al., "Platelet serotonin promotes the recruitment of neutrophils to sites of acute inflammation in mice," Blood, vol. 121, no. 6, pp. 1008$1015,2013$.

[168] N. Herr, M. Mauler, T. Witsch et al., "Acute fluoxetine treatment induces slow rolling of leukocytes on endothelium in mice," PLoS ONE, vol. 9, no. 2, Article ID e88316, 2014.

[169] B. Passlick, D. Flieger, and H. W. L. Ziegler-Heitbrock, "Identification and characterization of a novel monocyte subpopulation in human peripheral blood," Blood, vol. 74, no. 7, pp. 2527-2534, 1989.

[170] N. V. Serbina, T. Jia, T. M. Hohl, and E. G. Pamer, "Monocytemediated defense against microbial pathogens," Annual Review of Immunology, vol. 26, pp. 421-452, 2008.

[171] A. A. Tokmakov, M. P. Kykhova, O. V. Koshkina, and V. I. Vasilev, "The effect of serotonin on the functional activity of monocytes," Tsitologiya, vol. 33, no. 1, pp. 81-87, 1991.

[172] D. H. S. Silverman, H. Wu, and M. L. Karnovsky, "Muramyl peptides and serotonin interact at specific binding sites on macrophages and enhance superoxide release," Biochemical and Biophysical Research Communications, vol. 131, no. 3, pp. 11601167, 1985.

[173] H. Nomura, E. Sato, S. Koyama et al., "Histamine stimulates alveolar macrophages to release neutrophil and monocyte chemotactic activity," Journal of Laboratory and Clinical Medicine, vol. 138, no. 4, pp. 226-235, 2001. 
[174] Z. Mikulski, Z. Zasłona, L. Cakarova et al., "Serotonin activates murine alveolar macrophages through 5-HT2C receptors," The American Journal of Physiology - Lung Cellular and Molecular Physiology, vol. 299, no. 2, pp. L272-L280, 2010.

[175] M. Freire-Garabal, M. J. Núñez, J. Balboa et al., "Serotonin upregulates the activity of phagocytosis through $5-\mathrm{HT}_{1 \mathrm{~A}}$ receptors," British Journal of Pharmacology, vol. 139, no. 2, pp. 457463, 2003.

[176] E. M. Sternberg, J. Trial, and C. W. Parker, "Effect of serotonin on murine macrophages: suppression of Ia expression by serotonin and its reversal by 5 -HT2 serotonergic receptor antagonists," The Journal of Immunology, vol. 137, no. 1, pp. 276282,1986

[177] G. Ménard, V. Turmel, and E. Y. Bissonnette, "Serotonin modulates the cytokine network in the lung: Involvement of prostaglandin $\mathrm{E}_{2}$," Clinical and Experimental Immunology, vol. 150, no. 2, pp. 340-348, 2007.

[178] J. J. Mandoki, N. Mendoza-Patiño, J. A. Molina-Guarneros, F. A. Jiménez-Orozco, M. A. Velasco-Velázquez, and M. J. García-Mondragón, "Hormone multifunctionalities: a theory of endocrine signaling, command and control," Progress in Biophysics and Molecular Biology, vol. 86, no. 3, pp. 353-377, 2004.

[179] J. C. Jackson, R. F. Walker, W. H. Brooks, and T. L. Roszman, "Specific uptake of serotonin by murine macrophages," Life Sciences, vol. 42, no. 17, pp. 1641-1650, 1988.

[180] W. E. Paul, Fundamental Immunology, Lippincott Williams \& Wilkins, Wolters Kluwer, 7th edition, 2012.

[181] M. Merad, P. Sathe, J. Helft, J. Miller, and A. Mortha, "The dendritic cell lineage: ontogeny and function of dendritic cells and their subsets in the steady state and the inflamed setting," Annual Review of Immunology, vol. 31, pp. 563-604, 2013.

[182] M. Merad and M. G. Manz, "Dendritic cell homeostasis," Blood, vol. 113, no. 15, pp. 3418-3427, 2009.

[183] S.-F. Hsu, P. J. O’Connell, V. A. Klyachko et al., "Fundamental $\mathrm{Ca} 2+$ signaling mechanisms in mouse dendritic cells: CRAC is the major Ca2+ entry pathway," The Journal of Immunology, vol. 166, no. 10, pp. 6126-6133, 2001.

[184] J. A. Roake, "Pathways of dendritic cell differentiation and development," Eye, vol. 9, no. 2, pp. 161-166, 1995.

[185] N. Li, J. E. Ghia, H. Wang et al., "Serotonin activates dendritic cell function in the context of gut inflammation," The American Journal of Pathology, vol. 178, no. 2, pp. 662-671, 2011.

[186] M. Montes, D. Mcllroy, A. Hosmalin, and A. Trautmann, "Calcium responses elicited in human $\mathrm{T}$ cells and dendritic cells by cell-cell interaction and soluble ligands," International Immunology, vol. 11, no. 4, pp. 561-568, 1999.

[187] N. A. Khan, J. P. Meyniel, and P. Deschaux, " $\mathrm{Ca}^{2+} /$ calmodulin and protein kinase $\mathrm{C}$ regulation of serotonin transport in human K562 lymphocytes," Cellular Immunology, vol. 172, no. 2, pp. 269-274, 1996.

[188] D. O. Slauson, C. Walker, F. Kristensen, Y. Wang, and A. L. de Weck, "Mechanisms of serotonin-induced lymphocyte proliferation inhibition," Cellular Immunology, vol. 84, no. 2, pp. 240-252, 1984.

[189] I. A. Khan, G. Bhardwaj, N. Malla, C. Wattal, and S. C. Agarwal, "Effect of serotonin on $\mathrm{T}$ lymphocyte proliferation in vitro in healthy individuals," International Archives of Allergy and Applied Immunology, vol. 81, no. 4, pp. 378-380, 1986.

[190] M. R. I. Young, J. L. Kut, M. P. Coogan, M. A. Wright, M. E. Young, and J. Matthews, "Stimulation of splenic T-lymphocyte function by endogenous serotonin and by low-dose exogenous serotonin," Immunology, vol. 80, no. 3, pp. 395-400, 1993.

[191] M. R. I. Young and J. P. Matthews, "Serotonin regulation of T-cell subpopulations and of macrophage accessory function," Immunology, vol. 84, no. 1, pp. 148-152, 1995.

[192] N. Cedeño, M. Urbina, F. Obregón, and L. Lima, "Characterization of serotonin transporter in blood lymphocytes of rats. Modulation by in vivo administration of mitogens," Journal of Neuroimmunology, vol. 159, no. 1-2, pp. 31-40, 2005.

[193] M. Urbina, S. Pineda, L. Piñango, I. Carreira, and L. Lima, " $\left[{ }^{3} \mathrm{H}\right]$ Paroxetine binding to human peripheral lymphocyte membranes of patients with major depression before and after treatment with fluoxetine," International Journal of Immunopharmacology, vol. 21, no. 10, pp. 631-646, 1999.

[194] T. Kurosaki, "B-lymphocyte biology," Immunological Reviews, vol. 237, no. 1, pp. 5-9, 2010.

[195] E. J. Meredith, M. J. Holder, A. Chamba et al., "The serotonin transporter (SLC6A4) is present in B-cell clones of diverse malignant origin: probing a potential anti-tumor target for psychotropics," The FASEB Journal, vol. 19, no. 9, pp. 1187-1189, 2005.

[196] R. M. Welsh, M. Y. Lin, B. L. Lohman, S. M. Varga, C. C. Zarozinski, and L. K. Selin, "Alpha beta and gamma delta T-cell networks and their roles in natural resistance to viral infections," Immunological Reviews, vol. 159, pp. 79-93, 1997.

[197] E. Vivier, D. H. Raulet, A. Moretta et al., "Innate or adaptive immunity? The example of natural killer cells," Science, vol. 331, no. 6013, pp. 44-49, 2011.

[198] Å. Betten, C. Dahlgren, S. Hermodsson, and K. Hellstrand, "Serotonin protects NK cells against oxidatively induced functional inhibition and apoptosis," Journal of Leukocyte Biology, vol. 70, no. 1, pp. 65-72, 2001.

[199] K. Hellstrand and S. Hermodsson, "Monocyte-mediated suppression of IL-2-induced NK-cell activation. Regulation by 5-HT(1A)-type serotonin receptors," Scandinavian Journal of Immunology, vol. 32, no. 2, pp. 183-192, 1990.

[200] K. Hellstrand and S. Hermodsson, "Enhancement of human natural killer cell cytotoxicity by serotonin: Role of nonT/CD16+ NK cells, accessory monocytes, and 5-HT1A receptors," Cellular Immunology, vol. 127, no. 1, pp. 199-214, 1990.

[201] K. Hellstrand, C. Czerkinsky, A. Ricksten et al., "Role of serotonin in the regulation of interferon- $\gamma$ production by human natural killer cells," Journal of Interferon Research, vol. 13, no. 1, pp. 33-38, 1993.

[202] M. G. Frank, D. R. Johnson, S. E. Hendricks, and J. L. Wieseler Frank, "Monocyte 5-HT $\mathrm{H}_{1 \mathrm{~A}}$ receptors mediate pindobind suppression of natural killer cell activity: modulation by catalase," International Immunopharmacology, vol. 1, no. 2, pp. 247-253, 2001.

[203] C. L. Sokol, G. M. Barton, A. G. Farr, and R. Medzhitov, "A mechanism for the initiation of allergen-induced $T$ helper type 2 responses," Nature Immunology, vol. 9, no. 3, pp. 310-318, 2008.

[204] E. Schneider, F. MacHavoine, R. Bricard-Rignault et al., "Downregulation of basophil-derived IL-4 and in vivo $\mathrm{T}_{H} 2 \operatorname{IgE}$ responses by serotonin and other organic cation transporter 3 ligands," Journal of Allergy and Clinical Immunology, vol. 128, no. 4, pp. 864.e2-871.e2, 2011.

[205] C. L. Sokol and R. Medzhitov, "Emerging functions of basophils in protective and allergic immune responses," Mucosal Immunology, vol. 3, no. 2, pp. 129-137, 2010. 
[206] N. van Panhuys, M. Prout, E. Forbes, B. Min, W. E. Paul, and G. le Gros, "Basophils are the major producers of IL-4 during primary helminth infection," The Journal of Immunology, vol. 186, no. 5, pp. 2719-2728, 2011.

[207] H. Matsuda, H. Ushio, G. P. Geba, and P. W. Askenase, "Human platelets can initiate T cell-dependent contact sensitivity through local serotonin release mediated by IgE antibodies," The Journal of Immunology, vol. 158, no. 6, pp. 2891-2897, 1997.

[208] B. L. Fanburg and S.-L. Lee, "A new role for an old molecule: Serotonin as a mitogen," American Journal of Physiology-Lung Cellular and Molecular Physiology, vol. 272, no. 5, part 1, pp. L795-L806, 1997.

[209] M. Symons and N. Rusk, "Control of vesicular trafficking by Rho GTPases," Current Biology, vol. 13, no. 10, pp. R409-R418, 2003.

[210] L. Pavón, G. Sandoval-López, M. Eugenia Hernández et al., "Th2 cytokine response in major depressive disorder patients before treatment," Journal of Neuroimmunology, vol. 172, no. 12, pp. 156-165, 2006.

[211] M. E. Hernández, D. Mendieta, D. Martínez-Fong et al., "Variations in circulating cytokine levels during 52 week course of treatment with SSRI for major depressive disorder," European Neuropsychopharmacology, vol. 18, no. 12, pp. 917-924, 2008.

[212] M. E. Hernandez, D. Mendieta, M. Pérez-Tapia et al., "Effect of selective serotonin reuptake inhibitors and immunomodulator on cytokines levels: an alternative therapy for patients with major depressive disorder," Clinical and Developmental Immunology, vol. 2013, Article ID 267871, 11 pages, 2013.

[213] A. González, F. Fazzino, M. Castillo, S. Mata, and L. Lima, "Serotonin, 5-HT1A serotonin receptors and proliferation of lymphocytes in major depression patients," NeuroImmunoModulation, vol. 14, no. 1, pp. 8-15, 2007.

[214] M. E. Hernandez, D. Martinez-Fong, M. Perez-Tapia, I. EstradaGarcia, S. Estrada-Parra, and L. Pavón, "Evaluation of the effect of selective serotonin-reuptake inhibitors on lymphocyte subsets in patients with a major depressive disorder," European Neuropsychopharmacology, vol. 20, no. 2, pp. 88-95, 2010.

[215] L. R. Watkins, E. D. Milligan, and S. F. Maier, "Spinal cord glia: new players in pain," Pain, vol. 93, no. 3, pp. 201-205, 2001.

[216] B. Banic, S. Petersen-Felix, O. K. Andersen et al., "Evidence for spinal cord hypersensitivity in chronic pain after whiplash injury and in fibromyalgia," Pain, vol. 107, no. 1-2, pp. 7-15, 2004.

[217] L. A. Nielsen and K. G. Henriksson, "Pathophysiological mechanisms in chronic musculoskeletal pain (fibromyalgia): the role of central and peripheral sensitization and pain disinhibition," Best Practice and Research: Clinical Rheumatology, vol. 21, no. 3, pp. 465-480, 2007.

[218] R. Dubner and K. M. Hargreaves, "The neurobiology of pain and its modulation," Clinical Journal of Pain, vol. 5, supplement 2, pp. S1-S6, 1989.

[219] M. F. Seidel and W. Müller, "Differential pharmacotherapy for subgroups of fibromyalgia patients with specific consideration of 5-HT3 receptor antagonists," Expert Opinion on Pharmacotherapy, vol. 12, no. 9, pp. 1381-1391, 2011.

[220] F. Wolfe, I. J. Russell, G. Vipraio, K. Ross, and J. Anderson, "Serotonin levels, pain threshold, and fibromyalgia symptoms in the general population," Journal of Rheumatology, vol. 24, no. 3, pp. 555-559, 1997.

[221] I. J. Russell, J. E. Michalek, G. A. Vipraio, E. M. Fletcher, M. A. Javors, and C. A. Bowden, "Platelet $3 \mathrm{H}$-imipramine uptake receptor density and serum serotonin levels in patients with fibromyalgia/fibrositis syndrome," Journal of Rheumatology, vol. 19, no. 1, pp. 104-109, 1992.
[222] E. Houvenagel, G. Forzy, O. Leloire et al., "Cerebrospinal fluid monoamines in primary fibromyalgia," Revue du Rhumatisme et des Maladies Ostéo-Articulaires, vol. 57, no. 1, pp. 21-23, 1990.

[223] L. S. C. Carvalho, H. Correa, G. C. Silva et al., "May genetic factors in fibromyalgia help to identify patients with differentially altered frequencies of immune cells?" Clinical \& Experimental Immunology, vol. 154, no. 3, pp. 346-352, 2008.

[224] M. Späth, T. Stratz, G. Neeck et al., "Efficacy and tolerability of intravenous tropisetron in the treatment of fibromyalgia," Scandinavian Journal of Rheumatology, vol. 33, no. 4, pp. 267270, 2004.

[225] L. M. Arnold, E. V. Hess, J. I. Hudson, J. A. Welge, S. E. Berno, and P. E. Keck Jr., "A randomized, placebo-controlled, double-blind, flexible-dose study of fluoxetine in the treatment of women with fibromyalgia," The American Journal of Medicine, vol. 112, no. 3, pp. 191-197, 2002.

[226] S. Sidibe, F. Saal, A. Rhodes-Feuillette et al., "Effects of serotonin and melanin on in vitro HIV-1 infection," Journal of Biological Regulators and Homeostatic Agents, vol. 10, no. 1, pp. 19-24, 1996.

[227] W. Z. Ho, R. Cherukuri, and S. D. Douglas, "The macrophage and HIV-1," Immunology Series, vol. 60, pp. 569-587, 1994.

[228] H. Choe, "Chemokine receptors in HIV-1 and SIV infection," Archives of Pharmacal Research, vol. 21, no. 6, pp. 634-639, 1998.

[229] B. Manéglier, G. J. Guillemin, P. Clayette et al., "Serotonin decreases HIV-1 replication in primary cultures of human macrophages through 5- $\mathrm{HT}_{1 A}$ receptors," British Journal of Pharmacology, vol. 154, no. 1, pp. 174-182, 2008.

[230] K. Yu, C.-L. Qiu, G.-B. Yang et al., "Alteration of serotonin transporter messenger RNA level in the peripheral blood mononuclear cells from simian/human immunodeficiency virus infected Chinese rhesus macaques (Macaca mulatta)," Brain, Behavior, and Immunity, vol. 24, no. 2, pp. 298-305, 2010.

[231] A. L. Zignego, A. Cozzi, R. Carpenedo et al., "HCV patients, psychopathology and tryptophan metabolism: analysis of the effects of pegylated interferon plus ribavirin treatment," Digestive and Liver Disease, vol. 39, supplement 1, pp. S107-S111, 2007.

[232] O. T. Sims, C. C. Whalen, L. G. Nackerud, and B. E. Bride, "Longitudinal effects of selective serotonin reuptake inhibitor therapy and cytokine-related depression on hepatitis c viral logs during antiviral therapy," Journal of Clinical Psychopharmacology, vol. 34, no. 1, pp. 80-84, 2014.

[233] J. L. Munoz-Bellido, S. Munoz-Criado, and J. A. GarcìaRodrìguez, "Antimicrobial activity of psychotropic drugs: selective serotonin reuptake inhibitors," International Journal of Antimicrobial Agents, vol. 14, no. 3, pp. 177-180, 2000.

[234] S. A. Stanley, A. K. Barczak, M. R. Silvis et al., "Identification of host-targeted small molecules that restrict intracellular Mycobacterium tuberculosis growth," PLoS Pathogens, vol. 10, no. 2, Article ID e1003946, 2014.

[235] C. Lass-Flörl, M. P. Dierich, D. Fuchs, E. Semenitz, I. Jenewein, and M. Ledochowski, "Antifungal properties of selective serotonin reuptake inhibitors against Aspergillus species in vitro," Journal of Antimicrobial Chemotherapy, vol. 48, no. 6, pp. 775779, 2001.

[236] N. Patocka and P. Ribeiro, "The functional role of a serotonin transporter in Schistosoma mansoni elucidated through immunolocalization and RNA interference (RNAi)," Molecular and Biochemical Parasitology, vol. 187, no. 1, pp. 32-42, 2013.

[237] C. Lass-Flörl, D. Fuchs, M. Ledochowski, C. Speth, M. P. Dierich, and R. Würzner, "Antifungal properties of 5-hydroxytryptamine (serotonin) against Candida species in vitro," Journal of Medical Microbiology, vol. 52, no. 2, pp. 169-171, 2003. 
[238] B. Zhai, C. Wu, L. Wang, M. S. Sachs, and X. Lin, "The antidepressant sertraline provides a promising therapeutic option for neurotropic cryptococcal infections," Antimicrobial Agents and Chemotherapy, vol. 56, no. 7, pp. 3758-3766, 2012.

[239] Alzheimer's Association, "2012 Alzheimer's disease facts and figures," Alzheimer's \& Dementia, vol. 8, no. 2, pp. 131-168, 2012.

[240] J. Hardy and D. J. Selkoe, "The amyloid hypothesis of Alzheimer's disease: progress and problems on the road to therapeutics," Science, vol. 297, no. 5580, pp. 353-356, 2002.

[241] E. C. Hersch and S. Falzgraf, "Management of the behavioral and psychological symptoms of dementia," Clinical Interventions in Aging, vol. 2, no. 4, pp. 611-621, 2007.

[242] S. I. Garssadi, Y. Mandi, K. Regely, B. Tarodi, and I. Beladi, "The inhibitory effect of interferon-alpha on the serotonin-induced impairment of human NK cell activity in whole blood," Brain, Behavior, and Immunity, vol. 7, no. 2, pp. 164-175, 1993.

[243] A. Palots, L. G. Pusks, K. Kitajka et al., "The effect of citalopram on gene expression profile of Alzheimer lymphocytes," Neurochemical Research, vol. 29, no. 8, pp. 1563-1570, 2004.

[244] I. Tesseur, A. A. Pimenova, A. C. Lo et al., "Chronic 5-HT receptor activation decreases $\mathrm{A} \beta$ production and deposition in hAPP/PS1 mice," Neurobiology of Aging, vol. 34, no. 7, pp. 17791789, 2013.

[245] S. Kopp and P. Alstergren, "Blood serotonin and joint pain in seropositive versus seronegative rheumatoid arthritis," Mediators of Inflammation, vol. 11, no. 4, pp. 211-217, 2002.

[246] W. Müller, B. L. Fiebich, and T. Stratz, "5-HT3 receptor antagonist als analgetics in rheumatic diseases," Zeitschrift für Rheumatologie, vol. 65, no. 6, pp. 546-552, 2006.

[247] S. Sacre, M. Medghalchi, B. Gregory, F. Brennan, and R. Williams, "Fluoxetine and citalopram exhibit potent antiinflammatory activity in human and murine models of rheumatoid arthritis and inhibit toll-like receptors," Arthritis \& Rheumatism, vol. 62, no. 3, pp. 683-693, 2010.

[248] A. Frobe, L. Cicin-Sain, G. Jones et al., "Plasma free serotonin as a marker for early detection of breast cancer recurrence," Anticancer Research, vol. 34, no. 3, pp. 1167-1169, 2014.

[249] B. Grygier, B. Arteta, M. Kubera et al., "Inhibitory effect of antidepressants on B16F10 melanoma tumor growth," Pharmacological Reports, vol. 65, no. 3, pp. 672-681, 2013.

[250] A. Serafeim, M. J. Holder, G. Grafton et al., "Selective serotonin reuptake inhibitors directly signal for apoptosis in biopsy-like Burkitt lymphoma cells," Blood, vol. 101, no. 8, pp. 3212-3219, 2003.

[251] W. M. Oldham and H. E. Hamm, "Heterotrimeric G protein activation by G-protein-coupled receptors," Nature Reviews Molecular Cell Biology, vol. 9, no. 1, pp. 60-71, 2008.

[252] G. B. Downes and N. Gautam, "The G protein subunit gene families," Genomics, vol. 62, no. 3, pp. 544-552, 1999.

[253] C. E. Hagan, J. O. Schenk, and J. F. Neumaier, "The contribution of low-affinity transport mechanisms to serotonin clearance in synaptosomes," Synapse, vol. 65, no. 10, pp. 1015-1023, 2011.

[254] N. L. Baganz and R. D. Blakely, "A dialogue between the immune system and brain, spoken in the language of serotonin," ACS Chemical Neuroscience, vol. 4, no. 1, pp. 48-63, 2013. 


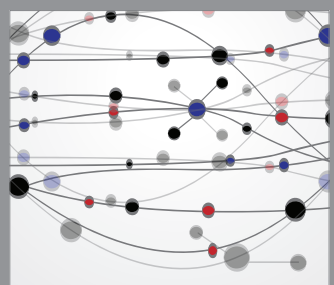

The Scientific World Journal
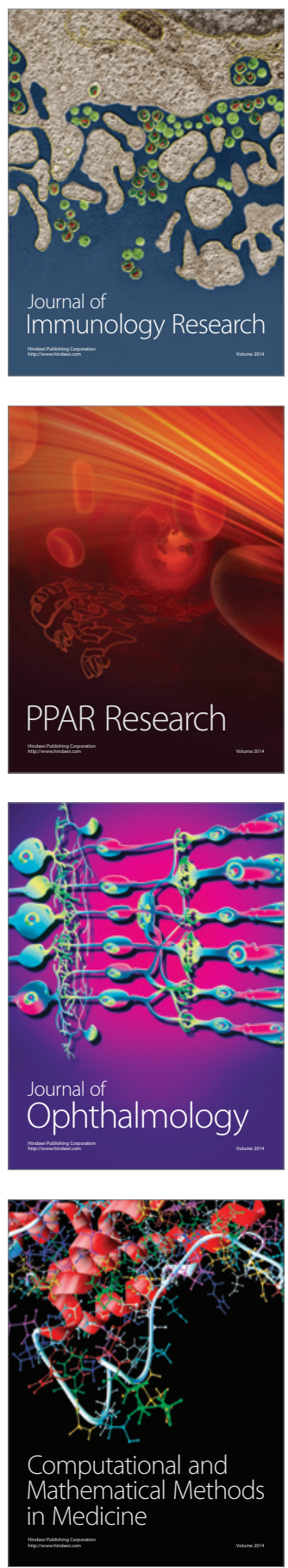

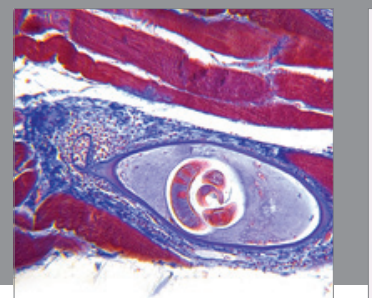

Gastroenterology

Research and Practice
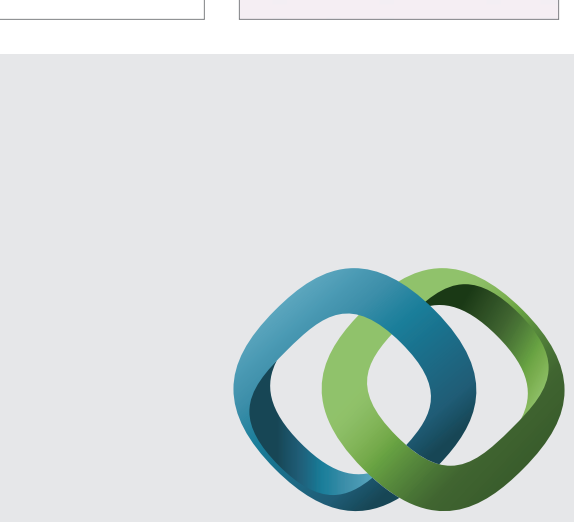

\section{Hindawi}

Submit your manuscripts at

http://www.hindawi.com
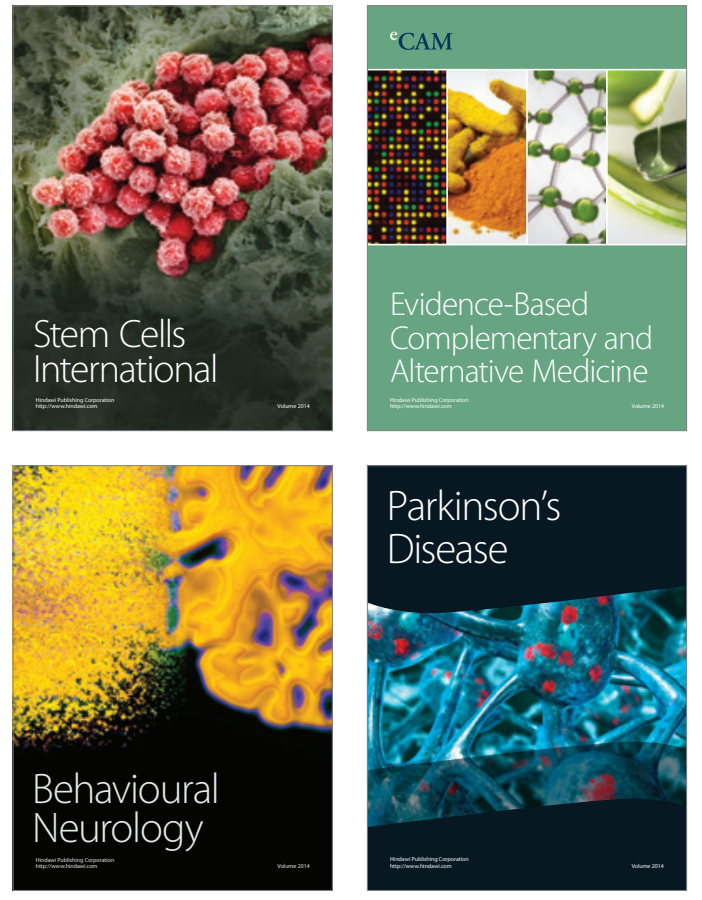
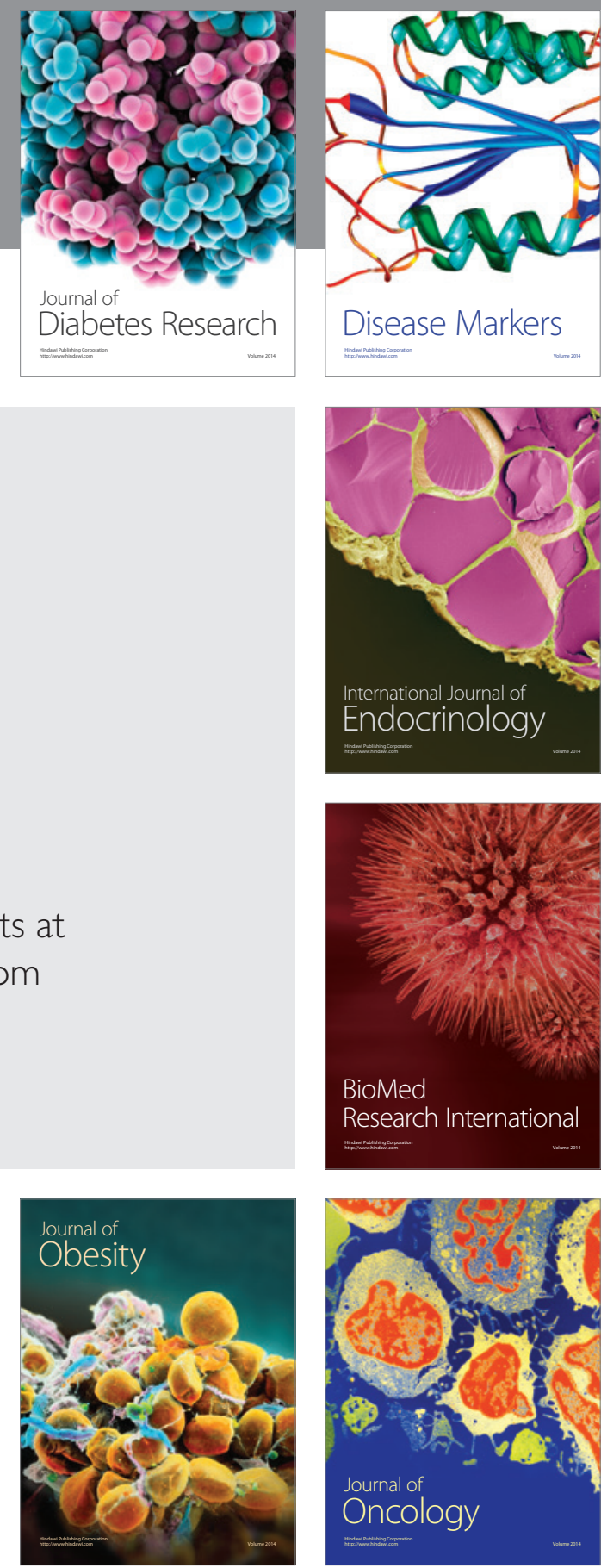

Disease Markers
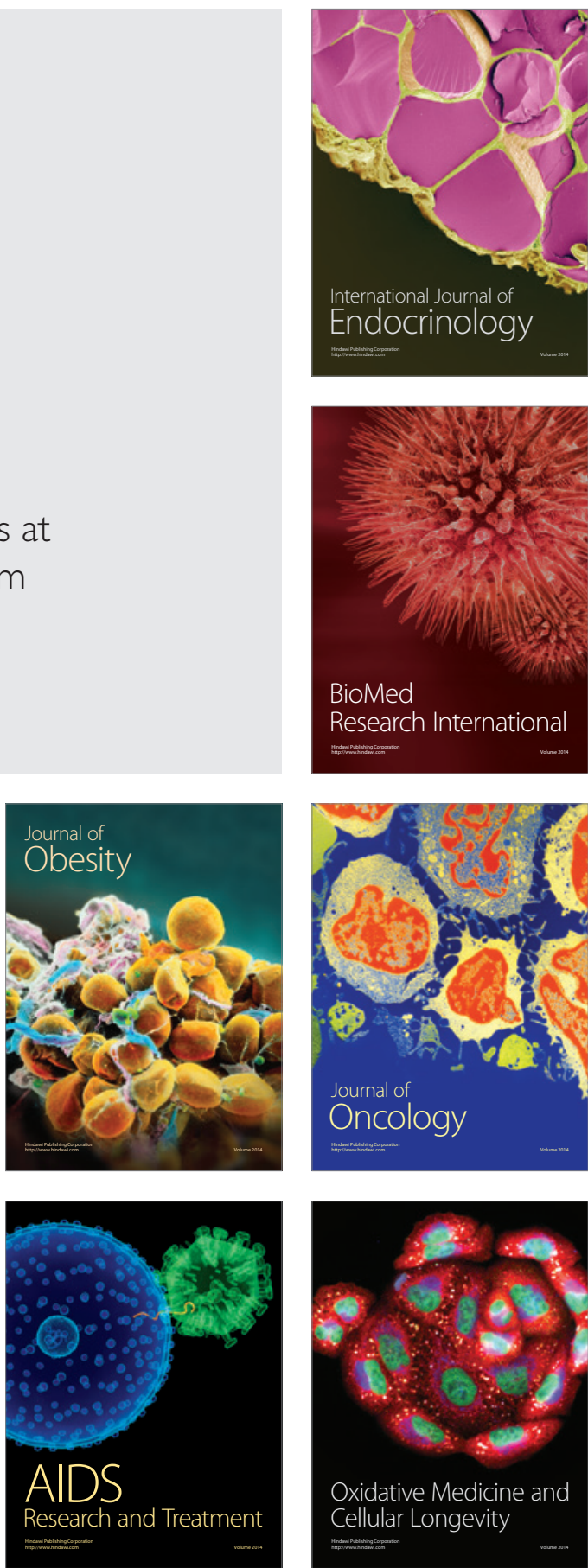